\title{
SO NO DAMN POLITICIAN CAN EVER SCRAP IT: THE CONSTITUTIONAL PROTECTION OF SOCIAL SECURITY BENEFITS
}

\author{
Matthew H. Hawes*
}

\begin{abstract}
We put those payroll contributions there so as to give the contributors a legal, moral, and political right to collect their pensions.... With those taxes in there, no damn politician can ever scrap my social security program.

President Franklin D. Roosevelt ${ }^{* *}$
\end{abstract}

\section{INTRODUCTION}

Is the nation's old-age pension system bankrupt? Each year brings repeated warnings of a need for immediate reform. Yet somehow, reasonable people and even experts dispute both the severity of the crises and the scope of the reforms, if any, that ought to be taken. Completely overlooked in the debate, however, are the legal and even constitutional limits to any reformation plan. President Roosevelt intended to create a program that would withstand political compromise - a program that would create a "legal, moral, and political right" to the receipt of benefits. Nearly seventy years after Social Security's creation, we must ask: Did Roosevelt succeed?

Any discussion of Social Security's reform must begin with an exploration of the program's vulnerability. When the chairman of the Federal Reserve Bank urges Congress to cut future Social Security and Medicare benefits for the sake of the nation's economic health, ${ }^{1}$ and the Bush Administration releases conservative estimates that the funding shortfall for the two programs will reach eighteen trillion dollars over the next seventy-five years, ${ }^{2}$ it certainly appears that Social Security is in danger.

\footnotetext{
* $\quad$ Matthew H. Hawes, Esquire, is an associate with the firm Davis Polk \& Wardwell in New York. He graduated summa cum laude in 2003 from the University of Pittsburgh School of Law. The opinions expressed in this article are the author's alone, and not those of Davis Polk \& Wardwell or its clients.

** Cong. Budget Office, Social Security: A Primer 14 n.4 (Sept. 2001), available at $\mathrm{ftp} / / / \mathrm{ftp} . c b o . g o v / 32 \mathrm{xx} / \mathrm{doc} 3213 /$ EntireReport.pdf (last visited Feb. 25, 2004).

1. Edmund L. Andrews, To Trim Deficit, Greenspan Urges Social Security and Medicare Cuts, N.Y. Times, Feb. 26, 2004, at A1.

2. Edmund L. Andrews, Fearing that a Gap will Become a Chasm, N.Y. Times, Mar. 2, 2004, at C1.
} 
Perhaps the clearest cry of alarm came from the nonpartisan Congressional Budget Office(CBO). ${ }^{3}$ In its 2003 report, Budget Options, the CBO describes Social Security and Medicare as two "looming strains" on the country's economy, and cautions, "[w]ithout changes to federal programs for the elderly, the aging of the baby-boom generation will cause a substantial deterioration in the fiscal position of the United States government." Citing the exponentially increasing cost of an unreformed Social Security program, the CBO exhorts: the nation must take action "sooner rather than later."

Yet not all agree. Less than one year before the CBO 2003 report, and shortly after the Social Security Trustees published their 2002 Annual Report on the health of the Old-Age and Survivors Insurance and Disability Insurance (OASDI) Trust Funds, ${ }^{6}$ Paul Krugman, a Princeton University professor of economics and columnist for the New York Times, likened the concerns over the imminence of Social Security's insolvency to a scene from "Monty Python and the Holy Grail." In the scene, a young man tries to convince an undertaker to accept an old man who repeatedly insists, "I'm not dead."

"There isn't any crisis," writes Krugman, ${ }^{8}$ rather the program's predicament has been overstated-Social Security does not yet belong on history's scrap-heap of failed social programs. Pointing out that the Trustees' report revealed that Social Security can operate without change or reduction in benefits three years longer than had been announced in the previous annual report, Krugman summarizes, "the system looks good for 40 years." course if, like Krugman, we choose not to look beyond the next generation, Social Security's health is fine.

But notwithstanding Krugman's short-term outlook, the repeated and dire long-term predictions, even if overstated, are such that the perception that Social Security faces long-term crisis is virtually unassailable. In their 2003 Annual Report, the Social Security Trustees forecast exhaustion of the trust

3. The Congressional Budget Office, a nonpartisan Congressional Agency tasked with analyzing the economic effect of legislative action and inaction, publishes the Budget Options report as a tool to help policymakers in the decision-making process. Cong. Budget Office, Budget Options, Preface (Mar. 2003) [hereinafter CBO, BUDGET OPTIONS], available at ftp://ftp.cbo.gov/40xx/doc4066/EntireReport.pdf (last visited Feb. 25, 2004).

4. Id. (italics added).

5. Id. at 254 .

6. 2002 Bd. of Trustees, Fed. Old-Age \& Survivor s Ins. \& Fed. Disability Ins. Trust Funds ANN. ReP. [hereinafter TRUSTEES' 2002 RePORT], available at http://www.ssa.gov/OACT/TR/TR02/ tr02.pdf (last visited Feb. 25, 2004).

7. Paul Krugman, Editorial, Connect the Dots, N.Y. Times, Apr. 2, 2002, at A23.

8. Id.

9. Id. 
fund in 2042, ${ }^{10}$ just one year later than their previous prediction. ${ }^{11}$ Exhaustion of the trust fund means that, beginning the year that Americans born in 1975 would otherwise receive full Social Security benefits, retirees will receive, at most, a mere seventy-three percent of their entitled payments. ${ }^{12}$ Even before that point, the $\mathrm{CBO}$ calculates that, without significant reform, payments under the current Social Security, Medicare, and Medicaid programs will consume fourteen percent of the gross national product $^{13}$ in 2030, a cost predicted to grow to twenty-one percent by $2075 .{ }^{14}$ At that point over one dollar in five generated by the economic output of the nation will be consumed in payments to retirees.

Why have these dire reports failed to trigger panicked attempts at reform already? One explanation may be that with the reports of the program's impending collapse dating back over thirty years, ${ }^{15}$ Americans already firmly believe the program is in financial crisis. ${ }^{16}$ In fact, one opinion poll of Generation $\mathrm{X}$ voters revealed that a greater number of young people believe

10. 2002 Bd. of Trustees, Fed. Old-Age \& Survivors Ins. \& Fed. Disability Ins. Trust Ann. REP. 3 [hereinafter TRUSTEES' 2003 REPORT], available at http://www.ssa.gov/OACT/TR/TR03/tr03.pdf (last visited Feb. 25, 2004). More specifically, the combined old-age insurance and disability insurance trust fund will be exhausted in 2042. Id. at 10 tbl.II.D1. Individually, the old-age insurance trust fund's exhaustion is predicted in 2044, and the disability insurance trust fund's exhaustion in 2028. Id. For a more complete discussion of the predicted exhaustion and its meaning, see discussion, infra notes 100-03 and accompanying text.

11. Compare Trustees' 2002 RePort, supra note 6 , at 3 with Trustees' 2003 RePort, supra note 10 , at 13. The annual change to the predicted exhaustion date is due, in part, to certain assumptions made by the Trustees in formulating the economic models for their report. For example, an assumed higher rate of immigration is one significant factor which delayed the predicted exhaustion date for the 2003 report by an additional year. See Trustees' 2003 Report, supra note 10, at 13.

12. Trustees' 2003 RePort, supra note 10 , at 8.

13. The gross domestic product is the total market values of goods and services produced by workers and capital within the United States' borders during a given year.

14. CBO, Budget Options, supra note 3, at 253.

15. See discussion infra Part II.D.i.

16. See Editorial, It's Surprising but Roberts is Right, Greensboro News \& ReC. (N.C.), Jan. 4, 2003, at A8, available at 2003 WL 5632472 (asserting "no one of even average intelligence believes" the platform of a recent candidate that Social Security is not broke); Editorial, Social Insecurity Overhaul of System Just Might Happen, DAILY OKLAHOMAN, Dec. 25, 2002, at 10A, available at 2002 WL 103885134 ("Young people understand better than what many of their elders obviously don't: Social Security will go bankrupt without major changes."); Steven Rattner, Big Shakeup! Fresh Faces! Political Capital! Too Bad All the Hoopla Doesn't Come with Any Real Change in Economic Policy, WASH. Post, Dec. 15, 2002, at A35, available at 2002 WL 104306641 (criticizing the 2002 Bush tax cut when "Social Security is going broke"). It may be the case that thirty years of dire predictions have simply numbed the nation to the point where it can no longer appreciate the scope of the current crisis. 
in the existence of UFOs than in the likelihood Social Security will be available to them upon their retirement. ${ }^{17}$

The politicization of the reformation debate, an outgrowth of the ever approaching funding shortfall, also explains some of Congress's failure to take any ameliorative action. Early predictions are that reform of the Social Security program and the possibility of private investment accounts will factor in the 2004 presidential race. ${ }^{18}$ Certainly candidates in the last national campaign, the 2002 congressional elections, did not hesitate to declare Social Security's insolvency. Senator John McCain, in an October 2002 interview with National Public Radio, reported that "Social Security is by any measure bankrupt." 19 Other politicians took even stronger positions. In her 2002 senatorial campaign, Elizabeth Dole promised: "I will not cut one single penny from the benefits of anyone on Social Security, and I won't vote to increase payroll taxes. I want to make Social Security stronger, or it will go broke."20 Federal Reserve Bank Chairman Alan Greenspan's warnings to

17. Timothy J. Penny, Facts Are Facts, National Review Online, Sept. 4, 2003, at http://www. nationalreview.com/nrof_comment/comment-penny090403.asp (last visited Feb. 25, 2004). Although frequently used by advocates of reform as a proxy for opinions on private accounts, see Edward H. Crane, President and CEO, Cato Institute, The Case for Privatizing America's Social Security System, Address at S.O.S. Retraite Santé, Paris, France (Dec. 10, 1997), at http://www.pensionreform.org/studies/crane.html (last visited Feb. 25, 2004), this often cited poll has now been called into question. In 1997, the Employee Benefit Research Institute (EBRI), a nonprofit, nonpartisan public policy research organization, conducted a study with the Gallup Organization yielding different results. News Release, EBRI, Public Attitudes on Social Security and Social Security and the UFO Fallacy (Apr. 7, 1998), available at http://www.ebri.org/prrel/pr411.htm (last visited Feb. 25, 2004). The president of EBRI, in testimony before the Subcommittee on Social Security of the House Committee on Ways and Means, reported that in its poll, $33 \%$ of generation X'ers believe UFOs are more likely to exist than Social Security upon retirement. The Future of Social Security for this Generation and the Next: Current State of Public Opinions as the Future of Social Security: Hearing Before the Subcomm. on Soc. Sec. of the House Comm. on Ways and Means, 105th Cong. (1997) (testimony of Dallas L. Salisbury, president of EBRI and chairman of American Savings Education Council). Though this report found fewer generation X'ers believing in UFOs, there is hardly cause for celebration; one third of America's youth remained absolutely convinced in the ultimate collapse of Social Security.

18. Adam Nagourney \& Richard W. Stevenson, Bush Advisers, With Eye on Dean, Formulate '04 Plans, N.Y. Times, Dec. 26, 2003, at A36.

19. NPR Talk of the Nation, Interview by Neal Conan, with Senator John McCain (Oct. 21, 2002), available at 2002 WL 3297261. Senator McCain cautioned that the challenge would only grow with both the nation's economic problems and the bankruptcy of major American corporations: "[N]ow that we're back into the deficit situations, we're taking away from the Social Security Trust Fund again .... And, by the way, the Social Security is not totally disconnected to the collapse of many pension systems in America." Id.

20. CNNfn, Moneyline News Hour with Lou Dobbs (CNNfn television broadcast, Nov. 7, 2002), Nov. 7, 2002, 2002 WL 6611221 (reporting on Senator Dole's plan to create private Social Security investment accounts). 
Congress may well have been intended to further force reformation into the presidential campaigns; but that does not mean that the nation will take action any sooner.

How critical is immediate reform? Of course, it is true that Social Security, as Krugman quips, is "not dead," and it is certainly not bankrupt. ${ }^{21}$ Rather, over the last thirty years, retirees have experienced numerous inflation-adjusted increases in their benefit amounts. Even in the midst of a funding emergency and decades of deficit spending, politicians have never tampered with this "third-rail" of American politics. ${ }^{22}$ Thanks to stopgap measures over the last thirty years, our elderly receive their checks on a regular basis and, at least for the near future, there is no risk of their vanishing.

21. Bankruptcy is a legal status established by the courts, while insolvency is the more appropriate term for the condition where liabilities exceed assets. The Social Security Administration more often chooses to use the term "exhaustion," rather than insolvency or bankruptcy, to describe the condition of the Social Security program upon the complete distribution of all funds that have been deposited in the trust fund. See supra text accompanying note 10. Although both "insolvency" and "exhaustion" are more legally precise, because the majority of the news media uses the term "bankruptcy," and therefore the vast majority of Americans similarly are apt to use the term as well, for purposes of this article, I too use the term bankruptcy as a simple catch-all.

22. E.g., Ramesh Ponnuru, Bush Takes On Medicare, NAT'L Rev., Feb. 24, 2003, at 21, available at 2003 WL 11520734 ("Political pundits have long described Social Security as 'the third rail of American politics ...."”); Roger Simon, The Campaign Games Begin, U.S. News \& WoRld ReP., Dec. 30, 2002, at 65, available at 2002 WL 8432184 (discussing the likelihood that President Bush will attempt to reform Social Security and thereby touch the legendary "third rail"). Commentators, such as Michael Tanner of the Cato Institute, have suggested that the Republican election victories in 2000 and 2002, victories achieved even though the Republican platform advocates privatization of Social Security, are evidence that the "third rail" is now dead. See Susan Page, Social Security Debate May Be Ready to Reignite; Democrats' Weapon No Longer Has Its Partisan Power, USA Today, Dec. 3, 2002, at A1 1 (discussing the possibility, and citing Michael Tanner for the view, that reforming Social Security is no longer instant political death). But this opinion is far from uniform. See, e.g., David E. Rosenbaum, Economic View; Hard Truths are Avoided on Social Security, N.Y. Times, Dec. 22, 2002, § 3 (magazine), at 4 (criticizing the opinion that George Bush's election in spite of his campaign promise to reform Social Security means it is no longer a "third rail"); John Harwood, Altered Landscape Doesn't Divert Bush from Stated Agenda, WALl ST. J., Dec. 11, 2002, at A4 ("Republican strategists don't buy White House political strategist Karl Rove's assertion that the third-rail of American politics—Social Security—has been unplugged ....”). Not to mention that Michael Tanner, a long-standing advocate for privatization, may simply be furthering his own agenda by suggesting that to reform Social Security in today's climate is no longer political suicide. See Michael Tanner, Union Workers Should Support Social Security Privatization, CATO InstituTe, Sept. 7, 1998, available at http://www.socialsecuirty.org/pubs/articles/bp-039.pdf (last visited Feb. 25, 2004); see also discussion supra notes 16-17 and accompanying text. Such manipulation, although accomplished through overstating the threats to Social Security's health, is precisely what Paul Krugman accuses the Bush Administration of in his article following the 2002 Trustees' Report. See Krugman, supra note 7 . 
But make no mistake - the Social Security system is in peril. ${ }^{23}$ The chicken-littles, while possibly premature in their cries, serve as harbingers of the future. Lower birth rates, increased longevity, and the ever advancing age of the baby-boomer generation guarantee the eventual insolvency of the system. Krugman need only read his annual Social Security statement to appreciate the calls for reform. Provided by the Social Security Administration (SSA), the agency tasked with maintaining the program, each Social Security contributor is annually warned:

[I]n just 15 years we will begin paying more in benefits than we collect in taxes. Without changes, by 2042 the Social Security Trust Fund will be exhausted. By then, the number of Americans 65 or older is expected to have doubled. There won't be enough younger people working to pay all of the benefits owed to those who are retiring. At that point, there will be enough money to pay only about 73 cents for each dollar of scheduled benefits. We will need to resolve these issues soon to make sure Social Security continues to provide a foundation of protection for future generations as it has done in the past. ${ }^{24}$

At least one commentator lays the blame for the recent and relative panic over Social Security's future with both libertarian and conservative thinktanks. These institutions, such as the Cato Institute and Heritage Foundation, "have been campaigning for years to convert Social Security into individual retirement accounts .... And they've dominated the debate so far, shaking confidence in Social Security's financial future with cries that the wolf of bankruptcy is just around the corner ...." 25

23. One newspaper succinctly summed, "[t]he problem with Social Security is not that it is completely bankrupt today, or even 10 years from today, but rather that it's slowly dribbling away even as baby boomers count their multiplying gray hairs." Jane Norman, Social Security Barbs Fly in Battle for Votes, Des Moines Reg., Oct. 28, 2002, at A1, available at 2002 WL 100689928.

24. Soc. Sec. Admin., Your Social Security Statement, Form SSA-7005-SM-Si (2003) [hereinafter Your Social SECURity StATEMENT], available at http://www.ssa.gov/mystatement/ currentstatement.pdf(last visited Feb. 25, 2004). This 2003 individualized Social Security statement varies markedly from the same report distributed to Social Security contributors in the previous year, conveying a far greater sense of urgency for the program's reforms. In 2002, the Your Social Security Statement merely called for the resolution of "long-range financial issues" and warned only of the approaching exhaustion of the trust fund and the reduction in benefits. By comparison, the 2003 statement not only informs of the approaching trust fund exhaustion and the reduction of benefits, but also apprises of the nation's aging population and program's imminent actuarial deficit in a mere fifteen years (the point at which Social Security taxes will no longer exceed current payments to retirees). Compare id. with Soc. Sec. Admin., Your Social Security Statement, Form SSA-7005-SM-Si (2002) (on file with author).

25. Saul Friedman, Social Security, Invest or Keep a Sure Thing?, NewSDAY, May 7, 2002, at B19, available at 2002 WL 2741867. Although one may speculate that Friedman's opinion is equally as biased as those of the think-tanks he criticizes, one thing is certain: the Cato Institute has not been quiet in its advocacy for reform. Shortly after the 2002 mid-term elections the Cato Institute held a Capitol Hill 
To date, the full predicted crisis, yielding a reduction in benefits or, even more drastic, the complete termination of the old-age insurance system, never materialized. As a result of thirty years of congressional "fixes"-each amendment postponing the bankruptcy of the program without a single reduction in benefits - the government has created an environment where it is reasonable to expect Congress to repair the program's immediate problems and remain, as it has for seventy years, virtually unaltered in all material respects. As a result, the nation is not prepared for the stark fact that this time the program might no longer be salvageable through simple, minor adjustments such as prospective changes to the retirement age. Inaction, the $\mathrm{CBO}$ warns, increases the likelihood of not only a reduction in the benefits for future retirees, but also raises the real specter of a "need for an abrupt increase in taxes or a cut in the benefits of all recipients." 26

But could Congress simply reduce the benefits of all recipients? Roosevelt's intention was to create a program granting legal, moral and political rights to benefits. In its advocacy for privatization of Social Security accounts, the Cato Institute argues that, unlike private accounts, the government has unlimited power under the current Social Security program to tinker with benefits, or even eliminate benefits altogether. ${ }^{27}$ One forty-fouryear-old Supreme Court case might provide support for such a contention.

In the much criticized, McCarthy-era decision of Flemming $v$. Nestor, ${ }^{28}$ the Court determined that the government acted constitutionally in terminating the social security benefits of a former member of the Communist party through a retroactive law on the grounds that there was no protectable right to continued payment of his benefits. However, since the decision was handed down in 1960, Nestor has never been revisited directly and the continued viability of this decision due to subsequent welfare law decisions must be questioned.

briefing entitled "The Third Rail is Dead." James G. Lakely, Democrats Cited for 'Scare Tactics, 'Social Security Reform Acceptable, 2 GOP Winners Say, WASH. Times (D.C.), Dec. 5, 2002, at A04, available at 2002 WL 2922865. The timing of the briefing can not be interpreted as anything other than a bid to overcome reticence and encourage legislation during the next Congress.

26. CBO, Budget Options, supra note 3, at 254.

27. Cato Institute, Answers to Frequently Asked Questions about Social Security, at http://www. socialsecurity.org/faqs.html (last visited Dec. 26, 2003); Cato Institute, Do I Have a Right to Social Security? (Jan. 13, 1999), at http://www.socialsecurity.org/daqilys/01-13-1999.html (last visited Dec. 26, 2003).

28. Flemming v. Nester, 363 U.S. 603 (1960). See discussion infra Part III. 
In particular, just one decade later, the Court, in the case of Goldberg $v$. Kelly, ${ }^{29}$ appeared to recognize broad property rights in the receipt of welfare assistance. Although ensuing decisions attempted to narrow Goldberg's holding, there is no question of an individual's right to the continued receipt of a vested benefit. ${ }^{30}$ The impact of Goldberg and its progeny on Social Security, however, remains unaddressed.

In this article, I seek to explore the historical, legal, and societal aspects of the federal old-age insurance plan as a justification for granting constitutional protections to a contributor's interest in Social Security-prior to the receipt of any retirement benefits. ${ }^{31}$ I intend to address the issue unaddressed in the case law: When does an individual's interest in Social Security receive constitutional protections?

The hypothetical situation arises under the following question: If the Social Security system were to fail, resulting in a complete and instantaneous termination of all benefits, would the contributing taxpayer have any constitutional recourse? Of course the total and complete bankruptcy of Social Security is merely academic; the political ramifications of such an event make it so remote as to be virtually laughable. However, only by exploring the outer limits of the government's power to act can we be certain that even more measured steps to reform Social Security will not impinge on the rights of the program's current and future beneficiaries. As such, discussion may provide a foundation for further analysis and debate on the constitutional implications of the various plans to repair the approaching exhaustion of Social Security.

The motives for the creation of the nation's largest social program are generally misunderstood. Rather than simply a plan to eliminate the elderly's burden on society, the system had a multiplicity of goals with an underlying purpose of easing the country out of the Depression. In Part II, I discuss the

29. Goldberg v. Kelly, 397 U.S. 254 (1970).

30. See Bowen v. Pub. Agencies Opposed to Soc. Sec. Entrapment, 477 U.S. 41 (1986); Mathews v. Eldridge, 424 U.S. 319, 332 (1976); Bd. of Regents v. Roth, 408 U.S. 564, 576 (1973).

31. For the sake of simplicity, when I refer to Social Security, I mean only the old-age insurance plan found in the original Social Security Act of 1935. Beginning with the addition of disability insurance in 1956 and continuing with Medicare in 1965 and Supplemental Security Income (SSI) in 1974, the Social Security Administration has been responsible for a broader range of social programs than provided for in the original legislation. The last two, Medicare and SSI, are distinctly different from the old-age pension and the disability insurance plans as they were not intended to be self-sufficient. Instead, funding of these programs relies on contributions from the general treasury to supplement the contributions from employers and employees. Consequently, they more resemble welfare plans than insurance plans and have generally been disregarded in this article. Where I intend to include Medicare or SSI in my analysis, I make specific reference to these programs. 
societal and legislative foundations of the Social Security system and how Social Security was intended to provide benefits as an earned right rather than a governmental gift. I explore the rationale behind the funding structure of the old-age insurance plan, that requires equal contribution from both employers and employees, and the intentions of its creators in designing it in this manner. I next examine the amendments to the original Social Security Act, which have led at least one commentator to describe the program's history as a "tale of two plans." And finally, I survey the current funding crisis as backdrop to the need for reform.

In Part III, I explore the constitutional principles governing Social Security. Notwithstanding its decision in Fleming v. Nestor, the Supreme Court's decisions inadequately address the scope of an individual's protectable interests should Congress ever decide to terminate Social Security. To this end, I analyze the Supreme Court's welfare-Social Security-property case law by exploring the inconsistencies and criticisms of the opinions. I investigate alternative theories, such as a contract theory and a "new property" theory, for explaining the relationship between Social Security and the individual. In Part IV, using the existing case law, I then examine Social Security's seventy year history and its effects on an individual's decisionmaking. By analyzing the pervasiveness of Social Security in modern retirement planning and the reliance the government has precipitated through its actions, I conclude with a discussion of how the government's actions created a right in future retirement benefits, which the existing law has created, but not yet recognized, and inadequately protects.

\section{Historical and Philosophical Foundations of the Social Security System}

Most likely believe Social Security origins lie in a Depression-era desire to protect the elderly from poverty. This is only a small part of the truth. The motivations behind the federal old-age insurance system are much more complex, stemming from factors such as a desire to remove older Americans from the workplace and constitutionality concerns over the program's structure. Though misunderstood, the true conceptual foundations have had an enormous impact on the program that is at once both good and bad. On one hand, the origins have immeasurably contributed to the creation of the future funding crisis that Social Security now faces, while on the other they have shaped the foundation of an individual's rights to future benefits earned by contribution. 


\section{A. To Help the Young (Not the Old)}

At the time Social Security was created, the idea for a governmentorganized old-age insurance plan was nothing new. ${ }^{32}$ A few vanguard European nations had first established national old-age pension systems over forty years earlier. ${ }^{33}$ In the United States, the first private pension plans date back to 1875 with the pension plan established by the American Express Company. ${ }^{34}$ By the turn of the century, many of the largest private corporations had established pension plans, but these generally required twenty or more years of service in exchange for limited payments. ${ }^{35}$

In contrast, until Social Security, the United States government had done little to provide for the nation's elderly. Although it had dabbled in veteran's pension systems as far back as the Revolutionary $\mathrm{War},{ }^{36}$ broad-based social insurance systems - plans that were not qualified upon service to the country in times of war-found little favor in the United States. ${ }^{37}$ America was founded on the principles of independence and self-determination. The nation was not eager to accept the premise that government, and not the family, had a duty to care for the elderly. Society as a whole was uncomfortable with the concept of a mandatory welfare system for the nation's retirees, as such a program carried the stigma of the government dole. ${ }^{38}$ As no small consequence, it took the need to aid young, able-bodied workers before sufficient catalyst existed to overcome the psychological hesitance towards a

32. For an excellent discussion of the historical antecedents of modern old-age insurance, see Patricia E. Dilley, The Evolution of Entitlement: Retirement Income and the Problem of Integrating Private Pensions and Social Security, 30 Loy. L.A. L. Rev. 1063, 1085-1106 (1997).

33. Id. at 1110-12.

34. William Graebner, A History of Retirement: The Meaning of an American INSTITUTION, 1885-1978, at 132-33 (1980).

35. Id. At the time of the Depression, the pension systems in America cannot be described as anything but a failure. As of 1932, eighty-five percent of all workers were not covered by any retirement insurance whatsoever. Id. As for the fifteen percent that were actually covered, most pensions were inadequate to keep retired workers out of poverty, and only five percent of those with a right to payments were actually receiving them. $I d$.

36. Veteran's pensions as compensation for sacrifices to the nation were widespread, dating back to the revolutionary war. See Patricia E. Dilley, Taking Public Rights Private: The Rhetoric and Reality of Social Security Privatization, 41 B.C. L. Rev. 975, 1026-27 (2000) (reviewing historical antecedents to the Social Security Act of 1935 as perspective on the privatization debate).

37. The Civil Service Pension took nearly twenty-five years of political wrangling from first conception in 1897 by the Secretary of the Treasury, to enactment on May 22, 1920 under President Woodrow Wilson. GRAEBNER, supra note 34, at 57.

38. See Martha Derthick, The Brookings Inst., Policymaking for Social Security 231 (1979). 
national old-age pension system. Social Security resulted from a motivation to help the young, not the old.

The 1930s witnessed years of depression and widespread unemployment. Large segments of the population did not share in the phenomenal growth of the industrial revolution. Unemployed youth, their families lured to the cities with the promise of opportunity, were pushed out of the workforce by mechanization. ${ }^{39}$ Slowly, a realization set in that capitalism was not the panacea for all of society's ills.

Social unrest accompanied the economic crisis. Sit-down strikes and veteran protests in Washington emerged causing great concern. ${ }^{40}$ These new threats challenged the very theories governing the country's economic and social policies from its birth; "laissez faire had lost its charm."

In this climate, Social Security was born. A fear of violence, primarily from the younger workers who blamed employers for their condition, was a major factor in the creation and design of the separate unemployment insurance and old-age insurance systems. ${ }^{42}$ But any solution to the rampant unemployment and accompanying unrest had to account for the expectations of the older, established, and generally still employed workers as well. According to J. Douglas Brown, one of the founders of Social Security, ${ }^{43}$ "[t]hose over 65, however, were too old to fight. They looked to the federal government to respect their rights as citizens ...."44

The solution reached by the Cabinet Committee on Economic Security (CES) was to encourage the removal of older, superannuated individuals from the workforce by providing sufficient pension payments upon retirement. ${ }^{45}$ In

39. GRAEBNER, supra note 34, at 194.

40. J. Douglas Brown, Philosophical Basis of the National Old Age Insurance Program, in PENSION Res. Council, Social Security and Private Pension Plans: Competitive or Complementary? 1, 4 (Dan M. McGill ed., 1977).

41. $\quad I d$. at 2 .

42. Id. at 4 .

43. In mid-1934, President Franklin D. Roosevelt created old-age security staff of the Cabinet Committee on Economic Security (CES) for the express purpose of creating an old-age insurance system. J. Douglas Brown, along with Barbara Armstrong, Murray Latimer, and Otto Richer, formed the CES. These four individuals single-handedly created the program eventually enacted in the Social Security Act of 1935. GRAEBNER, supra note 34, at 184-90.

44. Brown, supra note 40, at 4.

45. See, e.g., Graebner, supra note 34, at 184 ("The Social Security Act was, therefore, a piece of retirement legislation, which promised to accomplish what other retirement legislation, had accomplished - the removal of people from the workforce."); Dilley, supra note 32, at 1067 ("Without a legally enforceable expectation of a predictable level of income - whether from private pensions, savings, or Social Security - until death, no worker could be expected to leave the work force voluntarily, which after all is the essence of the twentieth century concept of retirement."). 
other words, Social Security, was not a system founded upon humanitarian principles or feelings of beneficence toward the elderly. Instead, it was seen as a means to address both unemployment and social unrest simultaneously through encouraging the retirement of those workers who had not saved for old-age or otherwise would not be able to support themselves without working.

Of course other factors influenced the old-age insurance plan. Considerations such as increasing consumer spending and capital investment in the national economy, and addressing the deterioration of the family support structure caused by the industrial revolution certainly were part of the equation. ${ }^{46}$ However, a significant hurdle remained; none of these justifications, let alone the creation of economic opportunity for the young and able-bodied worker, were adequate to receive the nation's, not to mention the Supreme Court's, approval.

Consequently, Social Security was packaged for the country and the Supreme Court as a welfare program providing a broad-based safety-net to keep the elderly out of poverty. ${ }^{47}$ To reach the ultimate conclusion that the Social Security Act of 1935 was constitutional under both the welfare clause ${ }^{48}$ and Congress's power to tax ${ }^{49}$ the Court found that Congress was responding to a national crisis of poverty amongst the elderly. ${ }^{50}$ The Court even cited extensive congressional hearings that support the notion that poverty was the primary motivation. ${ }^{51}$

But regardless of the legislative record, the structure of the benefits system, with a qualifying contribution level and fixed retirement age, provides the greatest insight into the true motivations behind the old-age insurance program. If relieving poverty of the elderly was the primary purpose of Social Security, the system might have been drafted to provide income to those elderly who voluntarily retire. After all, if someone is still capable of working, they are still capable of earning - there is no need to prevent poverty. ${ }^{52}$ Instead, the CES fixed the retirement age below the age at which all individuals would no longer physically be capable of working. Not only that, but a qualified taxpayer may choose to take an early retirement with

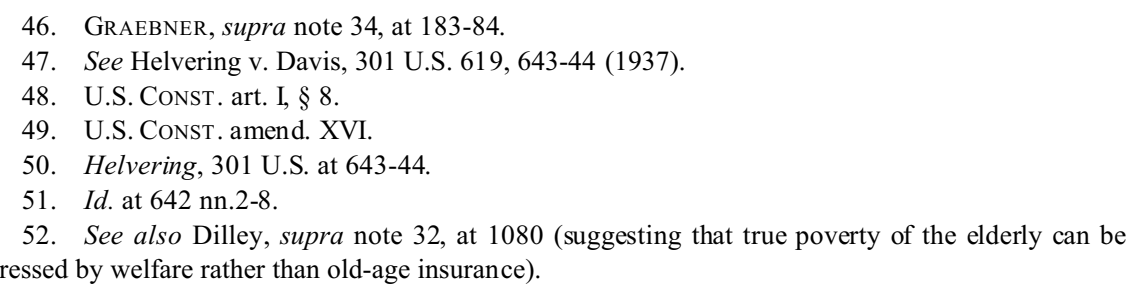


reduced benefits - an option that encourages those who have saved over a lifetime of working to depart the workforce.

This is not intended to completely discount the goal of providing income for the elderly in their retirement. Certainly, the collapse of the stock market followed by the virtual disintegration of the entire banking structure decimated the savings of an entire generation. However, providing for the elderly was in large part a pretextual justification used to sell the nation on the old-age insurance plan. The removal of the older workers from the nation's factories was the primary goal; replacing the lost savings of millions of individuals to liberate them from the need to continue working was the means to an end.

The Social Security system was revolutionary-it would provide old-age security to nearly all of the nation's elderly. It was cheap-funded and administered by contributions from employers and workers, and not requiring additional general taxes until well into the future. It was self-sufficient - contributions from younger workers would fund the benefits paid to retired workers. But it was also far from perfect.

\section{B. The Ever Growing Problem}

Despite being advertised as a self-perpetuating social insurance plan, the Social Security system has been at risk since its inception. ${ }^{53}$ J. Douglas Brown concedes the founders knew the program would not remain solvent and estimated that government contributions would be necessary as early as 1967 in order to stave off the plan's collapse. ${ }^{54}$ Writing in 1977, he noted that "as the number of beneficiaries increased, .. . [the] reserve," which is a limited purpose, contingency trust fund designed to protect from short-term fluctuations, "would be insufficient to avoid the need for a sharper rise in the [tax] contribution rate than then seemed feasible. It was at this point that a government contribution would be necessary." ${ }^{95}$

Congress, however, has consistently rejected calls for support from general revenues. ${ }^{56}$ Even in times of fiscal crisis, legislators refused to turn

53. See Carl V. Patton, The Politics of Social Security, in The Crisis in Social Security: Problems and Prospects 147, 150 (Michael J. Boskin ed., 2d ed. 1978). Even President Roosevelt was under the misconception that Social Security would be self-sustaining from inception. Id. Upon learning that contributions from the general treasury would be necessary in the late $1960 \mathrm{~s}$, Roosevelt insisted that the tax rates be changed, to ensure the program's solvency, absent further tinkering, until the 1980s. Id.

54. Brown, supra note 40 , at 10 .

55. Id.

56. DERTHICK, supra note 38, at 239 (noting that Congress rebuffed both the 1937-39 and 1947-48 Advisory Council when it recommended contributions from the general treasury). 
to this alternative source of funding, preferring to maintain a "self-supporting" system - at least in common expectation.

Such expectations were quickly dispelled when in 1972, a twenty percent benefits increase coupled with a change in the formula for inflation adjustments led to the first official report of a long-range deficit. ${ }^{57} \mathrm{~A}$ prediction of the complete exhaustion of the trust fund within twenty years spurred debate over the need for significant new sources of revenue. ${ }^{58}$ Although faced with a critical shortfall, Congress rejected President Jimmy Carter's proposal to use general funds to shore-up Social Security in 1977. ${ }^{59}$ Instead, Congress felt that it was more politically feasible to raise the wage base (the maximum income upon which contributions are calculated) for both employers and employees and to raise the payroll tax rate. ${ }^{60}$

It is particularly telling that Congress decided to raise taxes, a move generally considered political suicide, rather than simply reallocate funds under the existing tax structure. In doing so, Congress rejected a plan that would have made Social Security more like a true welfare program. Instead of taking money from general revenues and redistributing it to the elderly, Congress continued the program under the strict principle of individual contributions.

Although the crisis came as a shock to the nation in the 1970's, Social Security's inherent flaws were known $a b$ initio by its founders and its proponents. So how could such a revolutionary program be implemented even though it contained a potentially fatal defect? The answer lies in 1935 and the challenges of ensuring that Social Security could even be realized.

\section{Funding the Trust}

In the push to establish a plan that would withstand constitutional scrutiny, ${ }^{61}$ the CES made a conscious decision to postpone addressing the

57. $I d$. at 386,388 .

58. Id. at 382 .

59. Id. at $408-10$.

60. Id. at 410 .

61. J. Douglas Brown recorded that not only was constitutionality a factor in design of the system, but that it would withstand scrutiny was ultimately in doubt. Brown, supra note 40, at 7. Years later he explained:

In our attempt to provide a legal basis for a national system, on the advice of four leading professors of constitutional law in the country, we invented a bifurcated device of contributions under the federal power of taxation and benefits under the federal power of appropriation which might get by the Supreme Court. 
long-term funding challenge. ${ }^{62}$ The mandatory withholdings by employers, put into effect almost immediately, provided a basis for an instant constitutional challenge. But the benefits, the CES rationalized, not scheduled to begin for another seven years, did not require fine-tuning. Instead, the funding problem was to be passed on to the First Advisory Council, a twentyfive member committee scheduled to be established immediately following a Supreme Court determination that the plan was constitutional. ${ }^{63}$

The CES's concerns as to the Act's constitutionality were quickly put to rest. Two years after passage of the statute, the Supreme Court, in companion cases Helvering v. Davis ${ }^{64}$ and Chas. C. Steward Mach. Co. v. Davis ${ }^{65}$ held the Social Security Act constitutional. The CES had achieved its goal; the Court found that Congress had operated within its powers of taxation and authority to promote the general welfare when it enacted the statute. It was

Id. at 7 .

62. Id. at 10. Brown writes:

In the haste to have legislation ready for the opening of Congress in January 1935, the old-age security staff of the Committee on Economic Security did not have the time or the inventiveness to develop a satisfactory program of benefits .... The critical mission was to make sure that a national, compulsory, contributory system of old-age insurance was established by Congress and approved as constitutional by the Supreme Court.

Id. See also Graebner, supra note 34, at 256. Even the Senators who debated the bill were aware of its questionable constitutionality. Senator George, Chairman of the Finance Committee, stated on the Senate floor:

$[T]$ here is very grave doubt of the constitutionality of the bill as it stands. I do not believe that any lawyer of experience would assert that the bill is free from constitutional question. I do not wish to expand the constitutional argument, because the Senate is not in a receptive mood .... [T] he only purpose of the bill is to set up a system of old-age annuity and unemployment insurance by the use of the taxing power, and by the creation of the annuity system and the old-age employment insurance system.

79 Cong. ReC. S9514 (daily ed. June 18, 1935) (statement of Sen. George).

The anticipated challenges to the Act's constitutionality dictated some curious results. To achieve constitutionality of the tax itself, the government had to structure its appearance like an excise tax on employment, as opposed to an individual income tax which would have demanded per capita application throughout the country. See Steward Mach. Co. v. Davis, 301 U.S. 548, 578-81 (1937). In addition, prior to the program's withstanding Supreme Court scrutiny, its proponents sought to disassociate any link between the tax and the benefits, even going so far as to significantly separate them in distinct provisions within the statute itself. Only one Senator peered behind the curtain during debates over the Act's passage stating "Congress, in titles II and VIII, knowing it cannot directly collect premiums to pay compulsory oldage annuities, is attempting to reach this result indirectly through the taxing power .... The premiums are collected as taxes under title VIII and the annuities paid as Federal old-age benefits under title II." 79 Cong. Rec. S9535 (daily ed. June 18, 1935) (statement of Sen. King). See also Derthick, supra note 38, at 199 . The Supreme Court, however, would ultimately respect such form over substance.

63. See Brown, supra note 40, at 10.

64. Helvering v. Davis, 301 U.S. 619 (1937).

65. Steward Mach. Co. v. Davis, 301 U.S. 548 (1937). 
1937, and the Advisory Council would have time to create a plan for implementing one of the most sweeping social programs ever undertaken in the country; after all, benefits were not due to begin until $1942 .{ }^{66}$

However benefits began in 1940 under an accelerated plan that provided a benefits program far more extensive than that found in the 1935 Act. $^{67}$ Rather than addressing the future funding shortfall, the Advisory Council turned its attention to matching current outlays to early excess revenues. In addition to the basic old-age retirement pension that was part of the original program, the Advisory Council created a benefit structure that provided Social Security payments to wives, widows and surviving children as well. In all fairness, the CES had considered such an expansion advisable, but it was the desire to match revenues generated to the benefits paid that permitted the realization of the expansion. ${ }^{68}$

If the taxes were generating more income than the program administrators wanted, why didn't they simply place it in a trust that could fund the expected future shortfall? This is a difficult question to answer, particularly in light of the CES's early expectations that the program would require government contribution before 1970. ${ }^{69}$ J. Douglas Brown, elected as chairman of the First Advisory Council following his service with the CES, records that " $t]$ he council recognized the need and justification for government sharing of cost, but recognized, as had the staff of the committee, that the contributions of the government should be postponed until the changing balance of tax income and benefit disbursements required such contributions."

Although the intention had been to create a self-perpetuating system, the 1940 decision to accelerate benefits and expand the class of beneficiaries was made unmistakably at the expense of a fully funded reserve. According to Martha Derthick, in order to achieve the self-funding the drafters desired, an accumulation of a $\$ 47$ billion reserve fund by 1980 was planned..$^{71}$ This plan came under attack by Republicans in 1937 as the First Advisory Council

\footnotetext{
66. Brown, supra note 40 , at 10 .

67. Id.

68. Id. at 10-11.

69. See discussion supra notes 53-54 and accompanying text.

70. Brown, supra note 40, at 11 . Brown discusses that the Advisory Council supported the idea of tripartite financing, funding through both payroll taxes from employers and employees in addition to government contribution through general taxes, "on the grounds that dependent old age had become a national problem and that the nation as a whole, not just the beneficiaries, would gain both materially and socially by the program." Id. at 12 . It recommended the eventual equal financing from all three sources.

71. DeRTHICK, supra note 38, at 232.
} Id. at 13 . 
established their agenda for implementing benefits under the Act. ${ }^{72}$ The Republicans believed that the temptation presented by excess revenues would be too much to resist, resulting in either liberalizing benefits or spending the money as part of the general treasury. ${ }^{73}$ Consequently, to avoid collecting significantly more money than was being paid, the Advisory Council found it necessary to expand the qualified benefit recipients. In amazing circular logic, the expansion of beneficiaries was implemented to eliminate the temptation to liberalize benefits thereby solidifying Social Security's funding shortfall for all future generations.

J. Douglas Brown contends that the decision to provide only contingency financing rather than a fully funded reserve was made by the CES over the objections of Secretary of the Treasury Henry Morgenthau. ${ }^{74}$ The Committee determined that a full, traditional trust was unnecessarily redundant; a fully funded reserve, invested in government bonds, offered the same guarantees that came from the government's ability to generate revenue to pay the bonds. ${ }^{75}$ In addition, a contingency reserve avoided problems of deflationary withdrawal to accumulate reserves and challenges of managing a huge investment fund. ${ }^{76}$ In any event, having withstood constitutional scrutiny of their program and anxious to spend the revenue it was collecting, Congress swiftly authorized the payment of benefits a full two years earlier than originally intended.

\section{A Tale of Two Plans}

In a rather poetic twist, a law firm secretary, Ida Fuller, was the Social Security program's first beneficiary. ${ }^{77}$ She received $\$ 22$ each month for thirtyfive years until her death at an age of over 100 years old. ${ }^{78}$ During Ida Fuller's life, Social Security, and even more to the point, the old-age insurance program, underwent massive transformations. The clearest reflection of the transformations is witnessed in the contribution structure. At the time the Social Security Act went into effect, Ida Fuller and her law firm each contributed $1 \%$ of her income up to a wage base of $\$ 3,000 .{ }^{79}$ Twenty years

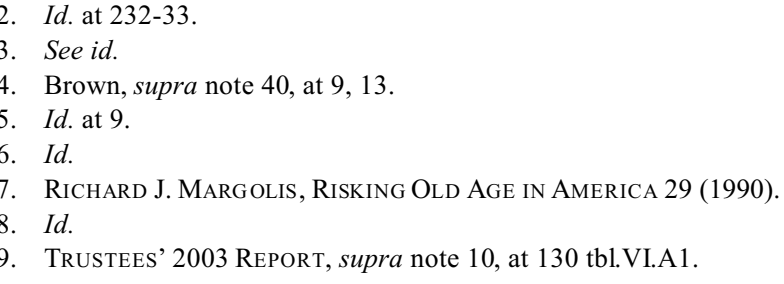


later, in 1960, the contribution rate increased for both employer and employee to $2.75 \%$ and the wage base to $\$ 4,800 .^{80}$ Today the contribution rate has increased to $5.3 \%$ on a wage base of $\$ 84,900 .^{81}$ At the turn of the twentieth century, approximately 39 million beneficiaries received payments averaging almost $\$ 10,000$ per year. ${ }^{82}$ Even adjusted for inflation, Ida Fuller's $\$ 22$ represents just over one-third of what the Social Security beneficiary receives today. ${ }^{83}$

\section{i. 1972 Amendments}

One commentator suggests that there have been two Social Security plans - the one originally created in 1935 and a contemporary one created by the massive overhaul of the system in $1972 .{ }^{84}$ Arguably, the most drastic modification made by Congress changed the manner in which benefits were adjusted from year-to-year. Under the original plan, Congress would occasionally, on an ad hoc basis, adjust the benefits level to reflect cost of living increases for the elderly. ${ }^{85}$ But with the 1972 amendments, the benefits thereafter automatically adjusted for inflation, removing one of the ways in which Congress historically accommodated unexpected shortfalls. ${ }^{86}$ In addition, on Advisory Council recommendation, Congress reduced Social Security's financing to meet the current costs and finance the trust fund to satisfy only one year's expenditures. ${ }^{87}$ This change marked a significant shift from the previous policy of ensuring that the revenue was sufficient to provide small, annual increases in the trust fund, which would be maintained at a level exceeding annual costs. ${ }^{88}$

Nonetheless, neither of these two financing modifications would likely have been significant enough to bring about a new era in Social Security were

80. Id. These numbers reflect the OASI contributions only as distinct from the combined contributions of OASI and disability insurance which is beyond the scope of this article.

81. Id.

82. See id.

83. Using the Consumer Price Index calculator provided on-line by the Federal Reserve Bank of Minneapolis, Ida Fuller's inflation adjusted payments of $\$ 22$ per month in 1940 are the 2001 equivalent to $\$ 278.30$ per month or $\$ 3,339.60$ per year. See $h t t p: / /$ woodrow.mpls.frb.fed.us/research/data/us/calc/ (last visited July 10, 2004).

84. DeRTHICK, supra note 38, at 12.

85. Id. at 384 .

86. See id.

87. Id. at 386

88. Id. at 385 . That is not to say that in 1972 the Social Security trust fund could fully fund the program indefinitely. See discussion supra Part II.C. 
it not for a combination of other factors - a combination which, in the aggregate, caused the program's first real crisis. First, financing changes were implemented not merely to reduce the size of the trust, but to fund an immediate increase of nearly twenty percent in the amount of benefits being paid. ${ }^{89}$ In addition, the program was no longer expanding to encompass new classes of employees. ${ }^{90}$ Finally, a significant economic downturn arrived at the same time the new financing plan was implemented. ${ }^{91}$ Increased unemployment and rapid inflation brought about decreased revenues and increased costs. In 1973, the Social Security Trustees' Annual Report included a projected shortfall over the next seventy-five years. ${ }^{92}$ Social Security was faced with its first actuarial deficit. ${ }^{93}$

The policy debate on how to fix the deficit raged. Some recommended contribution from the general treasury,${ }^{94}$ while others advocated less drastic action. Ultimately, in 1977, Congress began by increasing both the tax rate as well as the wage base rate. ${ }^{95}$ In addition, the 1972 amendment tying benefits to the consumer price index was repealed. ${ }^{96}$ Such measures, however, were only stop-gap. The cumulative effect of congressional tinkering and attendant reticence to alter the program's benefit structure remained which virtually guarantees the aging baby-boomers will one day bring Social Security to the brink of collapse.

\section{ii. Social Security Today}

A snapshot of a single year's balance sheet makes one wonder how we ever came to crisis. Net contributions to the OASI trust fund totaled $\$ 455.2$ billion in $2002 .{ }^{.7}$ In contrast, only $\$ 388.1$ billion in net benefits were paid

89. DERTHICK, supra note 38 , at 384-86.

90. Id. at 386 . The 1935 plan had already been expanded to include farm workers and independent professionals, so the only hold-outs left were government workers. Id.

91. Id. at 384 .

92. Id. at 381. In 1975, the Trustees first projected a short-run (less than ten years) deficit and the commis sioner testified before Congress that there would be trust fund exhaustion by the early 1980 s absent additional revenue. Id. at 381-82; Financing the Social Security System Hearing Before the Subcomm. on Soc. Sec. of the House Comm. on Ways and Means, 94th Cong. 3-38 (1979).

93. DERTHICK, supra note 38, at 381-82.

94. See supra note 54-55 and accompanying text.

95. DERTHICK, supra note 38 , at 391 .

96. Id. at 408. The debate over "decoupling" the benefits from inflation was particularly rancorous. See id. at 392-408.

97. Trustees' 2003 RePORT, supra note 10, at 4, tbl.II.B.1. It is important to note that the social security trustees are responsible for both the OASI and the Disability Insurance (DI) trust funds. Their 
during the same period. ${ }^{98}$ With approximately 39.2 million beneficiaries receiving payments, ${ }^{99}$ the average beneficiary received payments of nearly $\$ 10,000$ during that year.

Yet, even though the OASI trust fund has not witnessed a decrease in net assets since $1982,{ }^{100}$ it is now almost axiomatic that the program will eventually be unable to make full benefit payments. The long anticipated gradual retirement of the baby-boom generation, coupled with continued low birth rates and increased life expectancy, all contribute to a problem for the future. ${ }^{101}$ Under the Social Security Trustees' "best estimates," 102 the intermediate actuarial assumptions for the future of Social Security, the OASI trust fund is anticipated to be exhausted in $2044 .^{103}$

But even this "best estimate" for total depletion of the trust fund understates the problem. A better reflection of the challenges facing Social Security can be found in the fact that beginning in 2018, and increasing as rapidly as the baby-boomer generation retires, the program will operate in the red. ${ }^{104}$ Under the current rates and schedules, the anticipated costs of the benefits owed will outstrip revenues generated by contributions in just fifteen years. Discounted to the present value, the combined unfunded obligation of the combined old-age and disability insurance programs due through 2077 totals $\$ 3.5$ trillion dollars. ${ }^{105}$

annual accounting appropriately provides both separate and combined accountings for the trust funds.

98. Id.

99. $I d$. at 29 .

100. Id. at 134-35 tbl.VI.A2 (showing a change of $2.4 \%$ between 1982 and 1983 when the trust fund assets decreased from $\$ 22.1$ billion to $\$ 19.7$ billion).

101. See id. at 8-9 \& 32-70.

102. The trustees make three estimates: high cost, low cost and intermediate, or "best," estimates. $I d$. at 1 . These estimates provide a range of potentialities from worst-case scenarios where mortality rates and birth rates both decrease, to actuarial "best-case" scenarios with high mortality and high birth rates.

103. Id. at 10 tbl.II.D1. The date for trust fund exhaustion is most often reported as 2042 in most "summaries" of the Trustee's report. See id. at 3. This date is accurate for the exhaustion of the combined old-age insurance trust fund with the disability insurance trust fund (expected to be depleted by 2028). Id. at 10 tbl.II.D1. The old-age insurance program alone, on the other hand, is predicted to be exhausted in 2044 under the intermediate assumptions. Id.

104. See id.

105. Id. at 10 . 


\section{Entitlement and Ownership-The Framework for Legal Protections}

\section{A. Fifth Amendment Entitlement}

Such a crisis necessitates firm, strong action. Needless to say, no such action has been forthcoming and as the massive voting block that is the babyboom generation approaches retirement it will only become more difficult for Congress to take the necessary steps to protect the program for all future beneficiaries. Today's economists generally agree that any plan to save Social Security from certain bankruptcy requires significant overhaul of the current benefit structure. ${ }^{106}$ Without action, the prognosis for Social Security is dismal. With action, its future improves. However, with each passing year, more drastic action will be required. Undergirding, and in some respects constraining, any congressional action are critical constitutional and legal rights which have never been fully explored. Chief among these are a contributor's property and contract rights to the receipt of Social Security benefits after a lifetime of making contributions.

Under the Fifth Amendment of the United States Constitution, the federal government cannot deprive an individual of property without due process of law. ${ }^{107}$ This concept, like most constitutional matters, is deceiving in its simplicity; the Fifth Amendment's Due Process Clause provides no definition of property and no explanation of the scope of the due process right. ${ }^{108}$

The basic principle behind the constitutionally protected property interest has been well established by the Supreme Court. Where traditional private property (e.g., real property ${ }^{109}$ and chattels, ${ }^{110}$ as well as its ancillary forms such as choses in action ${ }^{111}$ ) is concerned, an individual has a right to an

106. See Richard W. Stevenson, The 2004 Campaign: Social Security; The Hot Potato of Issues is Dropped Anew, N.Y. Times, Feb. 27, 2004, at A21.

107. U.S. Const. amend. V ("No person shall be ... deprived of . . . property, without due process of law ....").

108. For example, is an individual entitled to a full evidentiary hearing with legal representation before the government executes a taking? Or is an administrative summary procedure with rights to appeal sufficient?

109. E.g., Penn Cent. Transp. Co.v. New York City, 438 U.S. 104 (1978) (addressing Penn Central's right to use its land to build office buildings).

110. See, e.g., Andrus v. Allard, 444 U.S. 51 (1979) (adjudicating property rights in Indian artifacts).

111. See, e.g., United States v. Sec. Indus. Bank, 459 U.S. 70 (1982) (deciding rights to statutorily created lien). 
evidentiary hearing and "just compensation." 112 Most disputes in this area, however, revolve around whether government action deprived the claimant of something of value ${ }^{113}$ and whether or not compensation is owed, ${ }^{114}$ not whether the claimant has a right to the property claimed.

When evaluating government action concerning government benefits, such as Social Security or state or federal welfare programs, individuals are entitled to due process "only if they have a constitutionally protected property interest." 115 Such a property interest is not created by the Constitution, but from an independent source such as state law. ${ }^{116}$ This source might take the form of a welfare benefit's administrative and statutory eligibility standards, like those at issue in Goldberg v. Kelly, ${ }^{117}$ or tenure provisions in public university employment. ${ }^{118}$

A mere expectation of continued receipt of a governmental benefit is not sufficient to confer a protectable interest. In an often quoted phrase, the Supreme Court explained:

To have a property interest in a benefit, a person clearly must have more than an abstract need or desire for it. He must have more than a unilateral expectation of it. He must, instead, have a legitimate claim of entitlement to it. It is a purpose of the ancient institution of property to protect those claims upon which people rely in their daily lives, reliance that must not be arbitrarily undermined. ${ }^{119}$

\section{B. Denying the Entitlement: Fleming v. Nestor}

By design, Social Security was intended to create benefits as a matter of right. ${ }^{120}$ Under the statute, qualifying for benefits was at the outset, and remains today, a simple matter: an individual need merely have contributed

112. U.S. Const . amend. V (stating that, "nor shall private property be taken for public use, without just compensation").

113. Cf. Goldblatt v. Hempstead, 369 U.S. 590 (1962)(determining that diminished value of property is not sufficient to show a "taking").

114. E.g., Brown v. Legal Found. of Wash., 538 U.S. 216 (2003) (holding the value of interest in Washington's IOLTA funds claimed by petitioners was nil, therefore the just compensation owed was nil).

115. Wash. Legal Clinic for the Homeless v. Barry, 107 F.3d 32, 36 (D.C. Cir. 1997) (citing Brock v. Roadway Express, Inc., 481 U.S. 252, 260 (1987); Bd. of Regents v. Roth, 408 U. S. 564, 569 (1972)).

116. Roth, 408 U.S. at 577.

117. Goldberg v. Kelly, 397 U.S. 254 (1970).

118. Slochower v. Bd. of Higher Educ., 350 U.S. 551 (1956).

119. Roth, 408 U.S. at 577.

120. See discussion infra Part III.C. 
a minimum amount to the program, ${ }^{121}$ reached a certain age, ${ }^{122}$ ceased working, ${ }^{123}$ and filed a claim. Such a formula appears to create a right to the benefits, but courts have been hesitant to recognize and protect that right.

In the 5-4 decision of Flemming $v$. Nestor ${ }^{124}$ the Supreme Court held that the Social Security Act conferred very little in the way of an entitlement. "To engraft upon the Social Security system a concept of 'accrued property rights' would deprive it of the flexibility and boldness in adjustment to ever-changing conditions which it demands." 125

In Nestor, the Court was asked to decide whether the termination of Social Security benefits being paid to the wife of a deported retiree violated the Fifth Amendment. ${ }^{126}$ Ephram Nestor, an alien who had emigrated from Bulgaria in 1913 began receiving old-age insurance benefits in $1955,{ }^{127}$ after working and paying his contribution to Social Security for eighteen years. ${ }^{128}$ In July 1956, Nestor was deported pursuant to a then recently enacted immigration law permitting the immediate deportation of communists and former communists; ${ }^{129}$ Nestor's deportation came fifteen years after he left the Communist Party. ${ }^{130}$ Shortly after his deportation, his Social Security benefits, being paid to his wife, were terminated. Nestor brought suit on the grounds that the termination of the benefits was a taking of an accrued property right without due process in violation of the Fifth Amendment. ${ }^{131}$

The Court recognized that Social Security was a form of social insurance, but refused to analogize it to an annuity where the individual's receipt of payments is contractually tied to premiums paid. ${ }^{132}$ While certainly reasonable to expect that a worker, who is supporting payments to current beneficiaries, will eventually become a beneficiary himself, the Court

121. See 42 U.S.C. $\S \S 410(a), 413-415$ (2000).

122. 42 U.S.C. $\S 402(a)(2)$.

123. See 42 U.S.C. $\S \S 403$ (b), (f). Strictly speaking, complete retirement is not necessary to receive benefits. Benefits may be decreased, or lost, if an individual earns more than a stated annual sum and is less than seventy-two-years-old. Id. If the individual is more than seventy-two-years-old, there are no earned income limitations. § 403(b).

124. 363 U.S. 603 (1960).

125. Id. at 610 (citing Elmer F. Wollenberg, Vested Rights in Social-Security Benefits, 37 Or. L. REv. $299,359(1958))$.

126. Id. at 603. Nestor's wife remained eligible for Social Security benefits "as the wife of an insured individual." Id. at 606 n.2 (citing 42 U.S.C. § 402(b)).

127. Id. at 605-06.

128. Id. at 621 (Black, J., dissenting).

129. Id. at 605 .

130. Id. at 621 (Black, J., dissenting).

131. Id. at 606 .

132. Id. at 609-10. 
reasoned the amount of his benefits is not "dependent on the degree to which he was called upon to support the system."133 Furthermore, the Court found that Congress's reservation of a right to alter, amend, or terminate any provision in the statute undermined all claims of accrued rights in the benefits conferred. ${ }^{134}$

Instead, the Court held that the Due Process Clause provides only the flimsiest of protections from arbitrary government action. ${ }^{135}$ It explained: "Particularly when we deal with a withholding of a noncontractual benefit under a social welfare program such as this, we must recognize that the Due Process Clause can be thought to interpose a bar only if the statute manifests a patently arbitrary classification, utterly lacking in rational justification."

133. Id. at 610 .

134. See id. at $610-11$ (citing 42 U.S.C. $\S 1304$ ).

135. See id. at 611.

136. Id. In addition to claiming that the Social Security benefits were an accrued property right, Nestor challenged the law calling for termination of the benefits following deportation, authorized on the basis of his past membership in the Communist Party, as an unconstitutional bill of attainder in violation of Article I, section 9, clause 3 of the Constitution ("No bill of attainder or ex post facto law shall be passed [by the Congress].”). Id. at 612-13, 613 n.6; U.S. Const. art. I, § 9, cl. 3.

Historically, a bill of attainder was a law passed by a legislature to punish an individual for advocating, attempting, or conspiring to overthrow the government. United States v. Brown, 381 U.S. 437, 441 (1965). Used extensively during the 16th, 17th, and 18th Centuries in England, bills of attainder and related acts not only sentenced the subversive individual to death, but also punished the family of the attained with penalties including prohibiting his or her heirs from inheriting property, restricting their right to vote, and even banishment. Id. at 441-42. In modern times, the Supreme Court has explained, "“[1]egislative acts, no matter what their form, that apply either to named individuals or to easily ascertainable members of a group in such a way as to inflict punishment on them without a judicial trial are bills of attainder prohibited by the Constitution." 'Id. at 448-49 (quoting United States v. Lovett, 328 U.S. 303, 315-16 (1946)).

Much to the chagrin of the dissent, see Nestor, 363 U.S. at 626-27 (Black, J., dissenting), the Court in Nestor held that the law requiring forfeiture of Nestor's Social Security benefits was not intended as punishment for his membership in the Communist Party and therefore did not constitute bill of attainder. Id. at 617. Relying, in large part, on the fact that the provision mandating the termination of benefits when the recipient was deported for specified acts was not accompanied with an expression of congressional purpose, the Court found no constitutional infirmity. Id. "[T] he presumption of constitutionality... forbids us lightly to choose that reading of the statute's setting which will invalidate it over that which will save it." Id. In essence, the Court refused to find that the grounds for Nestor's deportation, membership in the Communist Party, and the attend ant benefits termination constituted punishment because the statute required termination of benefits when deportation was ordered for illegal entry and conviction of a crime, in addition to Communist Party membership - the subversive activity and sole basis for Nestor's deportation who otherwise was legally in the United States and had committed no crime. Id. at 619-20. Therefore, the Court reasoned, the case was still "a far cry from the situations . . . in [previous decisions where laws were found to be bills of attainder] where the legislation was on its face aimed at particular individuals." Id. at 619.

Interestingly, if today's Court were to review Nestor's claim it would likely reach a different result. Just five years after Nestor, the Court, in United States v. Brown, struck down a provision of the Labor- 


\section{An Earned Right: Criticisms of Nestor}

\section{i. Contract Theory and Justice Black's Dissent}

Although specifically declaring Social Security as a "noncontractual benefit," the Nestor Court failed to provide any cognizable explanation as to why the old-age insurance program did not function as a contract between the contributing worker and the government like more traditional pension systems. Such cursory treatment, however, is not surprising when one conducts an analysis of a contract theory for Social Security.

It is a basic principle that a promise can create a unilateral contract. ${ }^{137} \mathrm{~A}$ promise is a self-created, self-imposed obligation. ${ }^{138}$ The Second Restatement of Contracts explains that a promise is "a manifestation of intention to act or refrain from acting in a specified way, so made as to justify a promise in understanding that a commitment has been made."139 That is not to say a promissory contract can only be entered into expressly; "whether it is appropriate to infer a promise depends on the facts of each case . .."140

Even where a court does not find express promissory language, it will not hesitate to infer a promise. ${ }^{141}$ In an employment situation such an inference might be grounded in nothing more than a past pattern of paying benefits. ${ }^{142}$

Management Reporting and Disclosure Act of 1959 which imposed a fine or imprisonment for a member of the Communist Party who served as an officer or employee of a labor union. Brown, 381 U.S. at 462. Rejecting the government's contention that the law was preventative not punitive as evidenced by the application to all members of the Communist Party rather than to individuals, the Court stated "[w]e cannot agree that the fact that [this law] inflicts its deprivation upon the membership of the Communist Party rather than upon a list of named individuals takes it out of the category of bills of attainder." Id. at 461 . "[T]he decisions of this Court, as well as the historical background of the Bill of Attainder Clause, make it crystal clear that these are distinctions without a difference." Id. The Court explained that Congress may permissibly seek to reduce the influence of dangerous people in the labor movement but it "must accomplish such results by rules of general applicability. It cannot specify the people upon whom the sanction it prescribes is to be levied .... [T] he task of adjudication must be left to other tribunals." Id.

137. See Mark Pettit, Jr., Modern Unilateral Contracts, 63 B.U. L. Rev. 551, 576-77 (1983).

138. Id. (citing Charles Fried, Contract as Promise 1 (1981)).

139. Restatement (SeCond) of Contracts § 2(1) (1981).

140. Pettit, supra note 137 , at 576.

141. Id. at 578 .

142. Id. (citing Allen v. Crowell-Collier Publ'g Co., 270 N.Y.S.2d 941 (N.Y. App. Div. 1966), rev'd, 235 N.E.2d 403 (N.Y. 1968) (severance pay)); Rose City Transit Co. v. City of Portland, 533 P.2d 339 (Or. 1975) (finding twenty-two-year custom of paying a pension to non-union employees bound the employer); Thatcher v. Wasatch Chem. Co., 507 P.2d 365 (Utah 1973) (finding employees expected bonuses would be paid to supplement paycheck); Simon v. Riblet Tramway Co., 505 P.2d 1291 (Wash. Ct. App. 1973) (finding bonus paid over ten year period ripened into an implied contract for compensation). 
Certainly such a past pattern is implicated in the case of Social Security payments where, even as of Flemming $v$. Nestor, neither current nor even future beneficiaries have ever been faced with a reduction in scheduled benefits. ${ }^{143}$

Because the Nestor Court provides no clear explanation, analysis, or support, one can only speculate how it reached the conclusion that Social Security does not create a contract between the beneficiary and the government. ${ }^{144}$ Perhaps the Supreme Court's rationale rests upon the premise that Congress specifically reserved the right to alter or amend the program, ${ }^{145}$ thereby disclaiming any possibility of an implied promise. It certainly cannot be based upon the suggestion that a worker's retirement benefits are not tied to the contributions made during employment as implied by the Court. ${ }^{146}$ That benefits are contingent upon sufficient contribution is, and always has been, one of the basic foundations upon which the old-age insurance plan is built. ${ }^{147}$

As already stated, courts are willing to find implied contracts, particularly in employment situations. ${ }^{148}$ Whether out of a sense of equity or a desire to enforce obligations, "[i]f a personnel manual or statement of company policy contains a description of existing benefit plans, courts often infer a promise that the employer will maintain these plans as described, even though ... the future existence of the plans [is never mentioned]." ${ }^{49}$ Even where employers specifically disclaim an intention to create contracts for continuations of benefits, courts look to the substance of the transaction to find a unilateral, contractual obligation. ${ }^{150}$ Whether the approach simply constitutes reimbursing reliance ${ }^{151}$ or an actual finding of obligation, "[i]t seems ... defensible to say that sometimes actions speak louder than words . ..."152

In one recent case, the Supreme Court looked through the strict form of a legislative disclaimer to identify the substance of the underlying action in a manner similar to the string of employment cases in which courts have found

143. See discussion supra notes 56-60 and accompanying text.

144. Flemming v. Nestor, 363 U.S. 603, 610 (1960) ("It is apparent that the noncontractual interest of an employee covered by the [Social Security] Act cannot be soundly analogized to that of the holder of an annuity, whose right to benefits is bottomed on his contractual premium payments.").

145. Id. at $610-11$.

146. See id. at 609-10.

147. See discussion infra notes $239-49$ and accompanying text.

148. Pettit, supra note 137 , at 578 .

149. Id. (citations omitted)

150. See id. at 578-79 (citing Davis v. Ala. Power Co., 383 F. Supp. 880 (N.D. Ala. 1974), aff'd, 542 F.2d 650 (5th Cir. 1976), aff'd, 431 U.S. 581 (1977)).

151. Id. at 579 n. 129 .

152. Id. at 579 . 
implied unilateral contract cases. In Lebron v. National Railroad Passenger Corp. ${ }^{153}$ the Court was asked to determine whether Amtrak, a privatized corporation created by congressional action, was a government actor for purposes of a claim the rail carrier violated an artist's First Amendment rights. Amtrak argued that it was a private corporation, wholly distinct from the government. ${ }^{154}$ In support of its claim, Amtrak pointed to a disclaimer of status as an agency of the government found in the authorizing legislation. ${ }^{155}$

Rejecting Amtrak's argument, the Court held that the disclaimer can only affect those powers within Congress's authority to eliminate. ${ }^{156}$ Because Congress reserved the right to appoint a majority of the board of directors, Congress did not have the ability to deny Amtrak's status as a government agency. ${ }^{157}$

We have no doubt, for example, that the statutory disavowal of Amtrak's agency status deprives Amtrak of sovereign immunity .... But it is not for Congress to make the final determination of Amtrak's status as a Government entity for purposes of determining the constitutional rights of citizens affected by its actions. ${ }^{158}$

Prior to Flemming v. Nestor, the Supreme Court in Lynch v. United States refused to allow Congress to disclaim its promises to pay beneficiaries under the War Risk Insurance Act of 1917..$^{59}$ Distinguishing the War Risk Insurance Act from gratuities such as pensions and compensation allowances ${ }^{160}$ the Lynch Court found that the war risk policies were contracts. ${ }^{161}$ Although entered into for benevolent purposes, the policies represented an agreement between the beneficiaries and the government-in exchange for premiums, the Court found the government became obligated to pay insurance for injuries incurred in war. Gratuities, the Court held, "involve no agreement of parties . . . . The benefits . . . may be redistributed or withdrawn at any time in the discretion of Congress." 162 The Court continued, "[o]n the other hand, War Risk policies, being contracts, are property and

153. Lebron v. Nat'l R.R. Passenger Corp., 513 U.S. 374 (1995).

154. Id. at 392 .

155. Id. at 391 (" $[\mathrm{I}] \mathrm{ts}$ authorizing statute declares that it "will not be an agency or establishment of the United States Government."') (citation omitted).

156. Id. at 392 .

157. $I d$. at 400 .

158. Id. at 392 (citations omitted).

159. Lynch v. United States, 292 U.S. 571 (1934).

160. Id. at 577 .

161. Id. at 576 .

162. Id. at 577 . 
create vested rights."163 Consequently, Congress's attempt to repudiate the contract constituted a Fifth Amendment violation. ${ }^{164}$

In Flemming $v$. Nestor, the Supreme Court barely acknowledged the existence of Lynch. ${ }^{165}$ Writing for the majority, Justice Harlan explained with a " $c f$ " signal to the Lynch case citation, "[i]t is hardly profitable to engage in conceptualizations regarding 'earned rights' and 'gratuities."'166 The Court acknowledged that '[ $t]$ he 'right' to Social Security benefits is in one sense "earned"" but this merely means that the contributors "may justly call upon [the] economy, in their later years, for protection from 'the rigors of the poor house." "167 Such a claim might very well have merit if Social Security were designed to draw up on the general revenue from the "economy" to pay benefits. But in a self-sufficient program, intentionally funded entirely through Social Security tax receipts, assertions that beneficiaries may "call upon [the] economy" are specious at best. ${ }^{168}$

In his dissent, Justice Black criticized the Court's cursory conclusions: that Lynch was inapplicable, and that the Social Security Act merely conferred a right to "justly call" for help in old age. ${ }^{169}$ Justice Black wrote:

These are nice words but they cannot conceal the fact that they simply tell the contributors to this insurance fund that despite their own and their employers' payments the Government, in paying the beneficiaries out of the fund, is merely giving them something for nothing and can stop doing so when it pleases. This, in my judgment, reveals a complete misunderstanding of the purpose Congress and the country had in passing that law. It was then generally agreed, as it is today, that it is not desirable that aged people think of the Government as giving them something for nothing. ${ }^{170}$

As Justice Black so competently points out, the very design of the contributory funding scheme for Social Security was to ensure it did not bear the imprint of the public dole. ${ }^{171}$ Rather than being a gratuity subject to the generosity of the government, benefits were conceptualized as an individually earned right - a right earned through contributions. ${ }^{172}$ Quoting Senator George, the Chairman of the Finance Committee, Justice Black continued:

163. Id.

164. Id. at 579-80.

165. Flemming v. Nestor, 363 U.S. 603, 610 (1960).

166. Id. (citing Lynch, 292 U.S. at 576-77).

167. $I d$.

168. $I d$.

169. Id. at 622 (Black, J., dissenting).

170. Id. at 623 (Black, J., dissenting).

171. See discussion infra Part III.C.

172. See discussion infra Part III.C; see also Brown, supra note 40, at 4. 
"It comports better than any substitute we have discovered with the American concept that free men want to earn their security and not ask for doles - that what is due as a matter of earned right is far better than a gratuity .... Social Security is not a handout; it is not charity; it is not relief. It is an earned right based upon the contributions and earnings of the individual. As an earned right, the individual is eligible to receive his benefit in dignity and self-respect." 173

Nor was Justice Black impressed by Congress's reservation of the right to "alter, amend, or repeal" the Act. ${ }^{174}$ This right, he explained, while a properly retained power, could not be applied to "disappoint[ ] the just expectations of the contributors to the fund which the Government has compelled them and their employers to pay its Treasury." 175 Justice Black

173. Nestor, 363 U.S. at 623 (Black, J., dissenting) (quoting 102 Cong. ReC. 15110 (1992) (statement of Sen. George)) (emphasis added).

174. Id. at 624-25 (Black, J., dissenting).

175. Id. (Black, J., dissenting). Where it suited its needs, however, the Supreme Court in Bowen v. Public Agencies Opposed to Social Security Entrapment, 477 U.S. 41 (1986), applied a "social security as a contract"-type analysis to find grounds for reversing a district court that held state employees had a property interest in the right to opt-out of the Social Security program. Id. at 43. See Michael W. McConnell, Contract Rights and Property Rights: A Case Study in the Relationship Between Individual Liberties and Constitutional Structure, 76 CAL. L. Rev. 267, 273-74 (1988) (noting "[t]he Court's reasoning is somewhat unclear ...," but seems to rely on a contracts clause analysis whereby Congress had given notice of a right to alter or amend the terms of the agreement).

Under the original plan for the old age insurance system, state employees were excluded from coverage to ensure the new statute would withstand constitutional scrutiny. Pub. Agencies Opposed to Soc. Sec. Entrapment, 477 U.S. at 44. Fifteen years later, Congress amended the Social Security Act to provide an opportunity for states to elect coverage for their employees, with an additional right to terminate participation after providing two years advanced notice. $I d$. at 44-45. After Congress revoked the right to opt-out in 1983, approximately 71,000 state employees in California brought suit claiming, in part, that the right to withdraw was "private property" under a contract theory and necessitating just compen sation under the Fifth Amendment. Id. at 49-50. The District Court for the North District of California agreed with the plaintiffs and declared Congress's revocation of the right to opt-out unconstitutional. Id. at 51. In reversing the decision, the Supreme Court held that the "the 'contractual right' at issue . . bears little resemblance to rights held to constitute 'property' within the meaning of the Fifth Amendment." Id. at 55. "The provision," the Court continued, "constituted neither a debt of the United States, nor an obligation ... to provide benefits under a contract for which the obligee paid a monetary premium[.]" Id. (citations omitted). Rather, the reservation of rights clause, which permits the alteration or amendment of the Act, conferred authority on Congress to revoke the opt-out provision without violating the Fifth Amendment. Id.

Unfortunately, Public Agencies Opposed to Social Security Entrapment provides little insight on the nature of the right inherent in the benefits plan itself. Considering that the old age insurance system does "provide benefits ... for which the obligee paid a monetary premium," $i d$. at 55, it would certainly appear the case in fact further supports a contract based analysis. Id. at 55. At the most, the case stands for the proposition that Congress may exercise its authority under the Reservation of Rights Clause to alter the Act and, upon alteration, further modify non-benefit related provisions without compensation. It certainly would be a leap to conclude that a contributor has no interest in all future benefits merely on the grounds that Congress may rescind a portion of an amendment which does not alter the underlying transaction. 
clarified that the reservation of rights, so important to the majority, meant nothing more than the power to terminate the program in the future, to cease covering new people, or even to cease increasing its obligations to existing contributors. ${ }^{176}$ But to terminate payments to an existing obligee is forbidden by the Fifth Amendment. ${ }^{177}$

A congressional intention to reserve the right to alter or amend the Social Security Act ${ }^{178}$ deserves no greater deference than Amtrak's authorizing statute or implied unilateral contracts in employment situations. In many respects, the equities found in employment situations, whether as an enforcement of an obligation or a remedy for reliance, are even more justifiable in Social Security. With an institution backed by the good faith and credit of the federal government, far more stable than virtually any employer, and having provided systematic payments for nearly seventy years, even when in crisis, ${ }^{179}$ the full circumstances appear far more likely to have created an implied promise enforceable as a contract than an employee benefits case- especially where the government itself encourages reliance on future Social Security benefits. ${ }^{180}$

\section{ii. Charles Reich and the New Property Theory}

In 1964, Professor Charles A. Reich proposed a radical new theory on welfare systems. ${ }^{181}$ Called "New Property," Professor Reich proposed that the pervasiveness of government social programs, which he termed largess, created a constitutionally protected property right in the beneficiaries. As one foundation of his theory, Reich rationalized that the expansion of the government, and more specifically its largess through both welfare programs and commercial contracts, was taking the place of private property.

The Great Depression led economists to fear a rapid increase in the nation's savings rate. The belief that an excessive savings rate would cause a permanent depression persisted until the 1940s. Social Security, they

176. Nestor, 363 U.S. at 624-25 (Black, J., dissenting).

177. $I d$. at 625 (Black, J., dissenting).

178. 42 U.S.C. $\$ 1304$ (2000).

179. See discussion supra Part II.D.

180. The Social Security Administration itself recommends that the benefits be considered part of the overall financial planning for retirement: "Remember! Social Security is an important part of your financial planning and helps you maintain your standard of living." Soc. Sec. Admin., Pub. L. No. 05-10024, Understanding the Benefits 7 (Feb. 2003) [hereinafter Soc. Sec. Admin., Pub. L. No. 05-10024], available at http://www.ssa.gov/pubs/10024.html (last visited Feb. 25, 2004).

181. Charles A. Reich, The New Property, 73 Yale L.J. 733 (1964). 
argued, would promote full employment by reducing the need for future savings. ${ }^{182}$ A simple example used by Harvard economics professor Martin Feldstein explains the effect:

For most Americans, the social security program is the major form of saving. Consider, for example, an individual with an income of $\$ 10,000$ who, in the absence of social security, would wish to save 10 percent of his total income for his old age. With social security, such an individual would not have to do any saving at all for his retirement. He need save only to buy consumer durables and to have a cash balance for emergencies. Similarly, an individual with an income of $\$ 20,000$ who, in the absence of social security, would want to save 10 percent of his income (or $\$ 2,000$ ), finds that social security now involves compulsory savings of about $\$ 1,800$. He would therefore need to save only an additional $\$ 200$ instead of $\$ 2,000$. $^{183}$

Professor Feldstein's numbers, while outdated due to increases in the maximum taxable wage rate since $1977,{ }^{184}$ are illustrative of a basic concept: Social Security causes, for the rational consumer, an adjustment in voluntary savings (and correlatively spending) in an inverse relationship based upon the amount of compulsory savings under the old-age insurance plan. As Social Security withholdings and benefits rise, individual retirement savings decline.

In 1971, Professor Feldstein evaluated the effects of Social Security on private wealth. He estimated the value of this Social Security "wealth" embodied in the old-age annuity of the Social Security system and compared it with total private wealth. His results were quite startling. He estimated that Social Security wealth, a term he reports he felt comfortable using because it was perfectly rational for households to rely on the expectation of receiving benefits upon retirement, was approximate $\$ 2$ trillion. ${ }^{185}$ By contrast, the stock of private wealth was estimated at $\$ 3$ trillion. Professor Feldstein concluded "social security may have reduced the stock of private wealth by about 40 percent." 186

Criticism in the Senate during the debates over passage of the Social Security Act evidenced congressional awareness of the likely effect that the old-age insurance plan would have on private wealth generally and private pensions in particular. Senator George stated:

182. Martin S. Feldstein, Social Security, in The Crisis in Social Security: Problems and Prospects 17, 21 (Michael J. Baskin ed., 2d ed. 1978).

183. Id. at 22 .

184. In 1977 , the wage base rate was $\$ 16,500$. Derthick, supra note 38 , at 432 .

185. Feldstein, supra note 182, at 23.

186. $I d$. 
Let me say that it was argued in committee that the private pension systems might still be maintained. I submit as a matter of plain common sense that the private systems will not, in fact, be maintained if the employers are subjected to a tax which they must in any event pay for the purpose of setting up an exactly similar system, or a system that has for its objectives the same general purpose. ${ }^{187}$

That Social Security would, in fact, reduce the quantity of private savings was one of the underlying economic rationales for creation of the pay-as-yougo, or pay-go, system. ${ }^{188}$ It was a bulwark principle of Keynesian economics that the gap between excessive savings and inadequate capital expenditure caused economic depression. ${ }^{189}$ While the continued viability of this economic theory is beyond the scope of this article, the legal impact has significant implications.

"Government is a gigantic siphon," Professor Reich, advocate of the New Property theory, explains, "[i]t draws in revenue and power, and pours forth wealth ...."190 This wealth takes many forms: licenses, services, contracts, subsidies, franchises, and benefits. ${ }^{191}$ The government, through direct and indirect means, controls large portions of the marketplace creating and conferring wealth to much of the nation. ${ }^{192}$ Social Security benefits, veteran's benefits, unemployment compensation, and the whole welfare scheme mean that "[f] or a large number of people, government is a direct source of income although they hold no public job." 193 Occupational licenses and franchises confer rights to work in a given field and legal protections from encroachment. ${ }^{194}$ Government contracts and subsidies are direct payments to engage or refrain from desirable or undesirable actions. ${ }^{195}$

Professor Reich contends the scope of the government's actions in the marketplace demands a new paradigm. Although the government's interaction with the nation's economy is nothing new, the pervasiveness of the largess means the old rules are no longer adequate. ${ }^{196}$ "In many cases, dependence

187. 74 Cong. Rec. S9515 (daily ed. June 18, 1935) (statement of Sen. George).

188. The Social Security pay-go system provides that revenues are used currently to pay current benefits owed as opposed to accumulated in anticipation of future promises made.

189. Geoffrey N. Calvert, Contrasting Economic Impact of OASDI and Private Pension Plans, in Pension Res. Council, Social Security and Private Pension Plans: Competitive or COMPlementary? 57-58 (Dan M. McGill ed., 1977).

190. Reich, The New Property, supra note 181.

191. Id. at 734-37.

192. See id.

193. Id. at 734 .

194. Id. at $734-35$.

195. See id. at 735-36.

196. See id. at 771-86. 
[on largess] is not voluntary. ... The taxpayer is a participant in [Social Security] by compulsion, and his ability to care for his own needs independently is correspondingly reduced." ${ }^{197}$ Similarly, the government has monopoly control in generation of licenses, public transportation, and public lands. Even dependence on technology, largely the product of government research, means an even greater dependence on the government. ${ }^{198}$ "[T] oday more and more of our wealth takes the form of rights or status rather than of tangible goods." 199

Pointing to Flemming v. Nestor, Professor Reich explains that current law provides inadequate protections for wealth that is generated and conferred by government's largess. ${ }^{200} \mathrm{He}$ equated the denial of an "accrued property right" to a feudal society, even a communist society, where indefeasible rights in property do not exist. ${ }^{201}$

The implications of Flemming $v$. Nestor are profound. No form of government largess is more personal or individual than an old age pension. No form is more clearly earned by the recipient, who, together with his employer, contributes to the Social Security fund during the years of his employment. No form is more obviously a compulsory substitute for private property; the tax on wage earner and employer might readily have gone to higher pay and higher private savings instead. No form is more relied on, and more often thought of as property. ${ }^{202}$

Consequently, Professor Reich called for greater acknowledgment of individual rights in government and expansion of constitutional principles to protect the same. ${ }^{203}$ In 1964, it was appropriate to view the application of the existing constitutional principles to Social Security as an "expansion" of the law. Forty years later, it is now far more appropriate to describe the law's application to Social Security as a recognition of the rights inherent to the program and the appropriateness of their constitutional protection.

197. Id. at 737 .

198. Id. To understand Reich's thesis, one need only consider the Global Positioning System - a creation of the military-industrial system. Id. at 737-38.

199. Id. at 738 .

200. Id. at 768 ("[W] ealth that flows from government is held by its recipients conditionally, subject to confiscation in the interest of the paramount state.").

201. See id. at 769-70.

202. Id. at 769 .

203. See id. at 783-86. Professor Reich explained:

Government largess, like all wealth, must necessarily be regulated in the public interest. But regulation must take account of the dangers of dependence, and the need for a property base for civil liberties. Rightly conceived, the public interest is no justification for the erosion of freedom that has resulted from the present system of government largess.

Id. at 777 . 
iii. Modern Entitlements: The Post-Nestor Progeny of Goldberg v. Kelly

The "New Property" theory achieved some recognition in Supreme Court jurisprudence. In what has been termed the "high water mark" of welfare due process protections, ${ }^{204}$ the Court granted property protections to welfare recipients based upon a concept of entitlement. Centered around a theory of constitutional protections for state law created property rights, the post-Nestor developments in welfare jurisprudence assume a critical role in understanding the continued viability, or more accurately the lack thereof, of the court's analysis in Nestor. Welfare benefits are the epitome of Professor Reich's governmental largess as welfare benefits are provided solely through the government's beneficence. Social Security, by contrast, is an earned right. Logic dictates that any property interests recognized by the Court for welfare recipients should be more ephemeral than those "bought" through contribution as in Social Security. Yet, just ten years after refusing to recognize any protectable rights for Social Security recipients, the Supreme Court first found constitutional protections for welfare beneficiaries in Goldberg v. Kelly. ${ }^{205}$

In Goldberg v. Kelly, New York State sought to terminate a federallyassisted welfare program called Aid to Families with Dependent Children (AFDC) without prior notice or a hearing. ${ }^{206}$ Existing city laws provided for post-termination relief in the form of a "fair hearing," but, the plaintiffs argued, this safeguard against improper termination was inadequate to provide due process protections afforded under the Constitution. ${ }^{207}$ The Court agreed. ${ }^{208}$

204. Richard J. Pierce, The Due Process Counterrevolution of the 1990's?, 96 Colum. L. Rev. 1973, 1982 (1996) ("Goldberg, and its welfare context, represented the high water mark."); Richard B. Stewart, Madison's Nightmare, 57 U. ChI. L. Rev. 335, 347 (1990); cf. Richard A. Epstein, No New Property, 56 BRoOK. L. Rev. 747 (1990) (describing the importance of Goldberg v. Kelly as "at the very top of secondtier" of important Supreme Court cases due to its impact on welfare jurisprudence).

205. Goldberg v. Kelly, 397 U.S. 254, 262 (1970).

206. Id. at 255-56. "AFDC was established by the Social Security Act of $1935 \ldots$. . It is a categorical assistance program supported by federal grants-in-aid but administered by the States according to the regulations of the Secretary of Health, Education, and Welfare." Id. at 256 n.1.

207. See id. at 258-60. Of course, this being a claim against a state authority, as opposed to a federal authority, the due process protection claimed by the plaintiffs was that provided by the Fourteenth Amendment. U.S. ConsT. amend. XIV, $\S 1$ ("[N]or shall any State deprive any person of ... property, without due process of law.").

208. Goldberg, 397 U.S. at 261. 
It held that "when welfare is discontinued, only a pre-termination evidentiary hearing provides the recipient with procedural due process."209 Distinguishing its earlier precedent where it found a post-termination hearing sufficient to satisfy the individual's due process rights, ${ }^{210}$ the Court determined that termination of welfare deserved special protections. Expressing a concern that "[f]or qualified recipients, welfare provides the means to obtain essential food, clothing, housing, and medical care," ${ }^{211}$ the Court reasoned that an individual ought not to be left destitute while awaiting a post-termination hearing. Due process does not mean that the government "may deprive an eligible recipient of the very means by which to live while he waits" 12 for his right to be heard. Rejecting an argument that public assistance is a privilege and not a right, ${ }^{213}$ the Court explained: "Such benefits are a matter of statutory entitlement for persons qualified to receive them." 14

The Supreme Court, in a footnote which had the potential to change the very definition of property in the United States, suggested this statutory grant was, in fact, "more like 'property' than a 'gratuity.",215 Quoting Charles A. Reich's Individual Rights and Social Welfare: The Emerging Legal Issues, ${ }^{216}$ the Court suggested:

"[S]ociety today is built around entitlement. The automobile dealer has his franchise, the doctor and lawyer their professional licenses, the worker his union membership, contract, and pension rights, the executive his contract and stock options; all are devices to aid security and independence. Many of the most important of these entitlements now flow from government: subsidies to farmers and businessmen, routes for airlines and channels for television stations; long term contracts for defense, space, and education; social

\section{Id. at 264 (citation omitted).}

210. Id. at 263 n. 10

See also, for example, Ewing v. Mytinger \& Casselberry, Inc., 339 U.S. 594 (1950) (seizure of mislabeled vitamin product); North American Cold Storage Co. v. Chicago, 211 U.S. 306 (1908) (seizure of food not fit for human use); Yakus v. United States, 321 U.S. 414 (1944) (adoption of wartime price regulations) .... In Cafeteria \& Restaurant Workers Union v. McElroy, [367 U.S 886,] 896 [(1961)], summary dismissal of a public employee was upheld because "[i]n [its] proprietary military capacity, the Federal Government, . . . has traditionally exercised unfettered control," and because the case involved the Government's "dispatch of its own internal affairs." Id. Cf. Perkins v. Lukens Steel Co., 310 U.S. 113 (1940).

211. Id. at 264 .

212. Id.

213. Id. at 262 (citing Shapiro v. Thompson, 394 U.S. 618, 627 n.6 (1969)).

214. Id. (footnote omitted).

215. Id. at 262 n. 8 .

216. Charles A. Reich, Individual Rights and Social Welfare: The Engaging Legal Issues, 74 YALE L.J. 1245 (1965) (expanding on Reich's New Property theory which had been published the year before). 
security pensions for individuals. Such sources of security, whether private or public, are no longer regarded as luxuries or gratuities; to the recipients they are essentials, fully deserved and in no sense a form of charity. It is only the poor whose entitlements, although recognized by public policy, have not been effectively enforced."217

The Supreme Court was taking notice that traditional common law definitions of property were inadequate to explain the nature of wealth in the country. ${ }^{218}$ Its holding in Goldberg recognized that expanded constitutional protections were necessary to reflect the realities of the modern economy.

The Supreme Court expanded the Goldberg holding into a complete entitlement concept just two years later in Board of Regents v. Roth. ${ }^{219}$ The Court explained that "[p]roperty interests . . . are not created by the Constitution. Rather, they are created ... [by] an independent source such as state law. . . ."220 For the plaintiffs in Goldberg, the Court continued, the welfare statute defined eligibility for benefits which, if qualified to continue to receive them, were subject to constitutional protections as property. ${ }^{221}$ Enunciating the rule, the Court explained: "To have a property interest in a benefit, a person clearly must have more than an abstract need or desire for it. He must have more than a unilateral expectation of it. He must, instead, have a legitimate claim of entitlement to it." 222

Although ultimately the Court found that Roth failed to show that he had more than a unilateral expectation of continued employment as a professor, ${ }^{223}$ the entitlement analysis has been applied to other property interests including civil service employment, ${ }^{224}$ professional licenses ${ }^{225}$ and even public school attendance. ${ }^{226}$ Perhaps most importantly, the Supreme Court, in Mathews $v$. Eldridge, found that receipt of Social Security disability benefits, albeit only continued receipt, is a "statutorily created 'property' interest protected by the Fifth Amendment." 227

217. Goldberg, 397 U.S. at 262 n.8 (quoting Reich, supra note 214, at 1255) (emphasis added).

218. $I d$.

219. 408 U.S. 564,577 (1972).

220. $I d$.

221. See id

222. $I d$.

223. $I d$. at 578 .

224. Cleveland Bd. of Educ. v. Loudermill, 470 U.S. 532 (1985).

225. Barry v. Barchi, 443 U.S. 55 (1979) (horse trainer's license); Leis v. Flynt, 439 U.S. 438 (1979)

(lawyer's right to appear pro hac vice).

226. Goss v. Lopez, 419 U.S. 565 (1982).

227. Mathews v. Eldridge, 424 U.S. 319, 332 (1976). 


\section{Pervasiveness and Reliance: Social Security as a Right}

The property right identified in the Goldberg-Roth-Mathews line of cases is not absolute. Rather, the Court found the protected right exists in the continuation of a benefit that have already begun. ${ }^{228}$ But unlike welfare payments or job tenure, which vest only after a determination of eligibility or mutuality of expectation has amassed, Social Security, as a very element of its creation, is a right earned before payments begin.

Although Congress passed the Social Security Act in large part to address the nation's problems of unemployment by encouraging retirement, ${ }^{229}$ its design represented the implementation of a radical new political philosophy concerning governmental intervention. ${ }^{230} \mathrm{~J}$. Douglas Brown attests that Social Security was founded on the theory that "American Citizens had a right to protection against distress caused by economic conditions beyond their control." 231 It was on this foundation that the Committee on Economic Security established the "old-age insurance system that would provide benefits as a matter of right." ${ }^{, 32}$ However, the right, as envisioned, was not granted to the elderly as a class of people, "but to each individual who had by his own contribution developed an individual right." ${ }^{233}$ The 1935 congressional debates, cited in Justice Black's Flemming v. Nestor dissent, bear out this conclusion. ${ }^{234}$

228. $I d$.

229. During the congressional debates over passage of the Act, one Senator explained to a critical colleague: "The purpose of the bill, as I understand, is to declare a new policy in this Nation; namely, that when people arrive at the age of 65 years they shall have, in effect, the right to retire." 102 CoNG. REC. S9528 (daily ed. June 18, 1935) (statement of Sen. Tydings).

230. Brown, supra note 40, at 3. Brown's co-drafter Murray Latimer is reported as having described the system as one where "[ $t$ ]hese younger employees would expect their contributions to purchase not only future annuities, but the removal of older workers and an increase the rate of promotion." GRAEBnER, supra note 34, at 188 (citing A Bill to Alleviate the Hazards of Old Age Unemployment, Illness, and Dependency to Establish a Social Insurance Board in the Department of Labor, to Raise Revenue, and for Other Purposes: Hearings on S. 1130 Before the Senate Comm. on Finance, 74th Cong. 744-45 (1935)).

231. Brown, supra note 40, at 3.

232. $I d$.

233. Id. at 4. E.g., DeRTHICK, supra note 38, at 21 (describing some basic dogmas in the operation of the Social Security system: that "people must qualify for benefits by making contributions (paying taxes)" and "[h] aving paid their contributions, they or their dependents should get benefits as a matter of right").

234. See discussion supra note 173 and accompanying text. 
Individualization is codified within the very benefits structure of the oldage insurance system. ${ }^{235}$ Individuals must qualify for retirement benefits based on a minimum level of contributions over a set period of time. ${ }^{236}$ And benefit payments are not fixed by class of recipients, but instead increase with a worker's increased contributions. ${ }^{237}$ Underscoring this individualization is the personalized Social Security Statement, sent out to all taxpayers, that informs " $[\mathrm{w}] \mathrm{e}$ [the Social Security Administration] can't provide your actual benefit amount until you apply for benefits." ${ }^{238}$

While application for benefits is necessary, Social Security is not welfare. The original drafters of the Social Security Act were concerned with prevention of poverty, not the alleviation of poverty. ${ }^{239}$ Consequently, they created an insurance system where a guaranteed minimum level of income is assured to retirees who contributed to the system. This is in contrast to a welfare system, designed to improve specific conditions caused by poverty. One is entitled to receive Social Security upon retirement merely by satisfying two conditions which are generally fulfilled as a matter of course: contribution through taxation, ${ }^{240}$ mandated by law and carried out by the employer, and reaching a specified age.

This formulation was essential to the program envisioned in 1935 by President Roosevelt. ${ }^{241}$ To Roosevelt, the old-age insurance program inherently depended on actuarial soundness and a distinction from welfare. ${ }^{242}$ "He believed that the program would only attain solid legitimacy if it was

235. See Brown, supra note 40 , at 4-5.

236. 42 U.S.C. $\$ \S 402(a), 414$ (a) (2000).

237. 42 U.S.C. $\S 415$ (a) (2000). By no means does Social Security pay beneficiaries in direct proportion to the amount contributed. While many commentators decry the regressive aspects of the Social Security system, see, e.g., Joseph A. Pechman, The Social Security System: An Overview, in THE CRISIS in Social Security: Problems and Prospects 31, 33-35 (Michael J. Baskin ed., 2d ed. 1978), the plain facts are that "benefits are weighted heavily in favor of the lower paid or short service worker." Paul $\mathrm{H}$. Jackson, Philosophical Basis of the Private Pension Movement, in Pension Res. Counsel, Social Security and Private Pension Plans: Competitive or Complementary? 14, 18 (Dan M. McGill ed., 1977).

238. Your Social Security Statement, supra note 24.

239. Brown, supra note 40 , at 4 . The drafters did use alleviation of poverty as a means to ensure the new program would withstand constitutional scrutiny. See discussion supra notes 46-52 \& 61-66 and accompanying text.

240. Of course a person can fail to qualify for Social Security by choosing to not work, but for those working, employers are legally obligated to remit Social Security withholdings. The fact that some may decide not to work is immaterial as I only explore the protectable interests of those who have made sufficient contribution to the Social Security system to qualify for benefits.

241. Joel F. Handler, "Constructing the Political Spectacle": The Interpretation of Entitlements, Legalization, and Obligations in Social Welfare History, 56 BrooK. L. Rev. 899, 916 (1990).

242. $I d$. 
'earned,' if it was financed by contribution, if it had no means test, if it clearly defined the risks, and if it had a fixed retirement age." ${ }^{243}$ The dignity of an earned right was necessary to avoid the stigma of welfare ${ }^{244}$ and achieve the program's widespread acceptance.

A number of commentators hold the position that continued viability of the Social Security system depends on a consumer's belief in the earned benefit. ${ }^{245}$ Should revenues be contributed from the general treasury, for example, the perceived bright-line connection between contribution and benefit would become blurred. George Break, professor of Economics emeritus at the University of California at Berkeley, projects that a tri-partite financing would result in fluctuating government contributions based on the economy's health and proposals to reduce benefits for the wealthy or create earnings tests. ${ }^{246}$ "Longtime contributors to the system — quite rightly-would see such proposals as abrogating the implicit contract under which they thought they had been providing for their own retirement and other needs. ${ }^{247}$ The political power of some of these disenchanted would bring about their own release from mandatory contribution. In turn, the program would simply become another federal welfare program. ${ }^{248}$

From the moment of its inception, the leaders of the Social Security Administration worked hard to depict Social Security as "insurance" in order

243. Id.

244. Id. at 917. See also supra note 38 and accompanying text.

245. See Edward Cowan, Background and History: The Crisis in Public Finance and Social Security, in The Crisis in Social Security: Problems and Prospects 1, 11 (Michael J. Baskin ed., 2d ed. 1978) ("[Some] argue strongly that public attitudes toward the payroll tax depend largely on their continued perception of the program as primarily committed to earned benefits.").

Although a full exploration of alternative theories is beyond the scope of this article, it is appropriate to note that not all commentators support the Reich-esque position of Social Security as a property right. In her recent paper on the Social Security privatization debate, Patricia E. Dilley rejects the New Property theory and proposes that Social Security is a right bec ause it is essential to the right of retirement. Dilley, supra note 36, at 1024. For Dilley, to consider Social Security as merely a property right under the New Property theory inadequately explains the nature of the benefit. Id. at 1023. She describes the claim to Social Security benefits as a "statutory claim, created by past work effort of the individual, on a portion of the future productivity of the work force at large and unmediated by any equity interest." Id. at 1022-23. Exploring the very foundations of the Social Security benefit and the nature of interest in future benefits held by the individual taxpayer, Dilley explains that the "public perception, which is supported by a broad based political will to maintain Social Security generally, and individual benefits in particular, in fact creates a real right whose existence is necessary to protect the public institution of retirement." Id. at 1024 .

246. George F. Break, Social Security as a Tax, in The Crisis in Social Security: Problems and Prospects 107, 120 (Michael J. Baskin ed., 2d ed. 1978).

247. $I d$.

248. $I d$. 
to secure the public's acceptance of the program. ${ }^{249}$ In her seminal book on the political development of Social Security, Martha Derthick, director of Governmental Affairs for the Brookings Institution, explained this was a conscious decision. "[B]ecause it implied a return in proportion to investment, it satisfied a widely held conception of fairness; and because it implied the existence of a contract, it appeared sound and certain." 250

For President Roosevelt, creating an aura of individual entitlement accomplished a slightly more practical goal: ensuring the program would not end up another casualty of politics following his departure from office. Commenting on the decision to fund the plan through equal contributions by employers and individuals, he remarked: "We put those payroll contributions there so as to give the contributors a legal, moral and political right to collect their pensions and their unemployment benefits. With those taxes in there, no damn politician can ever scrap my social security program."251 Roosevelt intended to create a "legal, moral and political right" so that taxpayers would fight to protect their future benefits - to fight for those benefits and to win.

In 1978, Carl Patton, director of the Bureau of Economic and Regional Planning Research at the University of Illinois, commenting on the crisis of Social Security solvency, wrote: "Most Americans think social security is a contributory insurance system from which they will receive benefits after reaching age 65. Many people believe their social security number is a retirement deposit account number-like a bank account number-which identifies a specific accumulation of funds." 252 Patton criticized the Social Security Administration for doing little to combat this myth, even when it describes the system:

"The basic idea of social security is a simple one: During working years employees, their employers, and self-employed people pay social security contributions into special trust funds. When earnings stop or are reduced because the worker retires, dies or becomes disabled, monthly cash benefits are paid from these funds to replace part of the earnings the family has lost." 253

249. DeRTHICK, supra note 38, at 199.

250. Id.

251. Dilley, supra note 36, at 1033 (footnote omitted).

252. Patton, supra note 53, at 152.

253. Id. at 153 (quoting a 1976 Social Security Administration Booklet). Patton also cites a booklet he received along with his Social Security card which stated: "Your card shows the number of your Social Security account. It is necessary to identify the account as belonging to you." Id. 
He contends that statements such as these leave the majority of people with the impression that they are saving for their own retirement as if they contributed to a guaranteed annuity program..$^{254}$

Surprisingly, such criticisms, and the continued problems with the solvency of the Social Security system, have failed to spur significant changes. Today, in the Social Security Administration's pamphlet "Understanding the Benefits," the system is described in almost identical terms. It states:

Social Security is based on a simple concept. When you work, you pay taxes into the Social Security system, and when you retire or you become disabled, you, your spouse and your dependent children receive monthly benefits that are based on your earnings. And, your survivors collect benefits when you die. ${ }^{255}$

The explicit assertion criticized by Patton, that revenues are placed into a trust fund, has been removed, but the annual statement still describes the program and the future payment of benefits in unequivocal terms. Any reasonable reading of the annual statement's claim that "when you retire ... you . . . receive monthly benefits that are based on your earnings" yields but one conclusion: that following a career of contributions payments will be forthcoming.

The Social Security Administration's augmentation of the belief that oldage insurance is "earned and owed" to the individual, a concept antithetical to the position that Social Security depends on government's continued beneficence and can be terminated at any time, does not end there. The annual statement notifies the individual whether or not they qualified for benefits. ${ }^{256}$ The statement even estimates an individual's future income in order to predict a specific dollar amount in retirement benefits that the contributor is likely to receive. ${ }^{257}$

254. Id. See also Dilley, supra note 32, at 1082 ("Supporters of Social Security ... actively promoted the public belief that each worker was in effect 'saving' for retirement . . . and that each worker's benefits in retirement were essentially a payout of the worker's contributions to the Social Security trust funds.").

255. Soc. Sec. Adm In., Pub. L. No. 05-10024, supra note 180, at 6. The most notable change is that the description no longer makes mention of the trust funds; for that one has to look elsewhere. See Soc. Sec. Admin.,Pub. L. No. 65-008, Social Security Handbook § 1403.2, available at http://www.ssa.gov/ OP_Home/handbook/handbook.pdf (last visited Feb. 25, 2004) ("During working years, employees, their employers, and the self-employed pay Social Security and/or Medicare taxes. The equivalent of these taxes is pooled in special trust funds under automatic appropriation by Congress.").

256. Your Social Security Statement, supra note 24, at 2 ("You have earned enough credits to qualify for benefits. At your current earnings rate, if you stop working . . . at age 62, your payment would be about ... \$[ dollar amount].”).

257. Id. ("We based your benefit estimates on these facts ...."). 
"It is a purpose of the ancient institution of property to protect those claims upon which people rely in their daily lives, reliance that must not be arbitrarily undermined." 258 Why doesn't the Social Security Administration's own attempt at hedging the expectations for the future of Social Security 259 succeed in defeating the reliance?

The statement only says that the Social Security Administration cannot predict the benefit amount and lists three reasons why such a prediction is not possible. Those reasons include a change in the individual's actual earnings before retirement, benefit changes caused by changes in the current $\operatorname{law}^{260}$ and other factors such as other pensions not covered by Social Security (military and railroad employment). Yet under all of these possibilities lies the promise that if the individual does continue to work, she will receive benefits in her retirement; if the individual has worked the requisite number of quarters, the statement informs: "You have earned enough credits to qualify for benefits." 261 Not only that, but the statement even assures that the specific benefit dollar amounts predicted for the individual taxpayer "will be adjusted for cost-of-living increases" prior to retirement. ${ }^{262}$ A contributor to Social Security is not merely led to believe that retirement benefits are likely, but that they are forthcoming. ${ }^{263}$ The cognoscenti may understand the tenuousness of old-age insurance, but the Social Security Administration certainly strives to assure the public that payments are virtually guaranteed.

It seems even more difficult for the government to make the case that it does not induce reliance on the future of Social Security when the Social Security Administration itself recommends that the benefits be considered part of the overall financial planning for retirement: "Remember! Social Security is an important part of your financial planning and helps you maintain your standard of living." 264

258. Bd. of Regents v. Roth, 408 U.S. 564, 577 (1972).

259. See Your Social Security Statement, supra note 24, at 1.

260. As a point of fairness to the Social Security Administration, the statement does tell the taxpayer that "by 2042 the Social Security Trust Fund will be exhausted," and "[a]t that point, there will be enough to pay only about 73 cents for each dollar of scheduled benefits." Id. But this report, joined with the rest of the paragraph discussing possible changes in the law that might effect the benefit amount, does not dispel the conclusion th at taxpayers will receive something at retirement in exchange for their contributions during their working life - a guarantee that can only be met through reformation of the current program.

261. Id. at 2 .

262. Id. ("These estimates are in today's dollars. After you start receiving benefits, they will be adjusted for cost-of-living increases.").

263. At age twenty-nine, I was assured that I had already earned enough credits to qualify for benefits. 264. Soc. Sec. Admin., Pub. L. No. 05-10024, supra note 180, at 7. The Social Security Administration's failure to dispel reliance on retirement benefits following a public commitment by one of 
Statements such as these have brought about one of the basic tenets of Reich's "New Property" theory_-government largess as a replacement for individual wealth. "The individual has little reason to do much ... saving any more." ${ }^{265}$ Social Security and employee benefits plans are looked at as a substitute "generally do[ing] a more systematic and efficient job of providing security to the worker and his family than he could do on his own."

\section{Conclusion}

So where does this leave Social Security's contributors should Congress fail to avoid the program's ever approaching fiscal crisis? Although Social Security is more than a mere "unfunded promise," underwritten by the generosity of the federal government, even the expectation and right to receive payments after retirement does not guarantee payments will be made. With all due regard for the political weight of the AARP, ${ }^{267}$ Congress retains the authority to terminate Social Security if it so chooses. But in spite of the Supreme Court's outdated case law, it is clear that termination of the program and the attendant cessation of current and future benefits will directly implicate the Fifth Amendment due process rights of Social Security's contributors.

While due process case law provides a basis for determining the constitutional implications of any governmental action effecting Social Security, the remedy provided by the Due Process Clause, that is a hearing before termination, is clearly insufficient to meet the needs of the individual contributor. A hearing is generally only beneficial in identifying the nature and scope of the property interest with an eye towards fashioning a remedy, assuming the authority to execute the taking already exists. Furthermore, the

its directors to do just that, provides additional insight into the grip Social Security maintains on the American psyche. See Deborah Churchman, Dorcas Hardy's Stamp on Social Security, Christian ScI. Monitor, Mar. 5, 1987, at 29.

Social security is an insurance policy that people have come to rely on for retirement - which is a mistake, she says. "If I have one responsibility, it's to remind [the baby boom generation, heading toward retirement] that the one with the primary responsibility to the individual's future is that individual." (alterations in original).

265. Geoffrey N. Calvert, Contrasting Economic Impact of OASDI and Private Pension Plans, in Pension Res. Council, supra note 40, at 57, 59.

266. $I d$.

267. The AARP, formerly known as the American Association of Retired Persons, is a 35 million member non-profit organization dedicated to addressing the needs and interests of people fifty-years-old and older. AARP, Fact Sheet, at http://www.aarp.org/leadership/Articles/a2002-12-18-aarpfactsheet.html (last visited Feb. 25, 2004). 
Supreme Court has held that the requirements of due process are satisfied through the legislative process. ${ }^{268}$ As a consequence, the due process clause would appear to be satisfied provided Congress identifies a sufficient remedy for the termination of a contributor's benefits. So rather than providing the means to fashion a remedy, the due process case law offers the vehicle to identify the property rights attendant with an individual's contributions to Social Security. Once a constitutional right to Social Security benefits is established, it is the Just Compensation Clause, rather than the Due Process Clause, that provides the appropriate starting place for any remedies discussion.

Although the government has the authority to confiscate private property, the Just Compensation Clause of the Fifth Amendment imposes two conditions on such confiscation: the taking must be for a "public use" and the owner of the confiscated property must rec eive "just compensation." ${ }^{269}$ As for the "public use" requirement, there is little doubt that any attempt to avert a budgetary melt-down, would constitute a public use. ${ }^{270}$ On its face, the required just compensation appears equally as straightforward-the government would be obligated to remit, at a minimum, the amount contributed by participants, plus interest. ${ }^{271}$ Yet the equation becomes far more complicated when trying to account for the payroll contributions from employers. Is the government required to return this amount to the employers who paid it, or to the employees who, economically speaking, sacrificed additional wages in exchange for the employer's tax? It may be that the original language of the Social Security Act identifying employer contributions as an excise tax, ${ }^{272}$ rather than an income tax, warrants

268. See City of West Covina v. Perkins, 525 U.S. 234, 241 (1999) (holding due process satisfied when individual receives notice of post-seizure remedies through "published, generally available state statutes and case law").

269. U.S. Const. amend. V; Brown v. Legal Found. of Wash., 538 U.S. 216, 231-33 (2003).

270. Of course whether or not avoiding the impeding Social Security crisis constitutes a public purpose, let alone whether there is an imminent crisis, is a matter of debate. Compare discussion supra Part I with discussion supra Part II.D.ii. The Congressional Budget Office, however, has estimated that in less than thirty years federal spending on the combined burden of Social Security, Medicaid and Medicare will constitute nearly two-thirds of federal budget and approximately fifteen percent of the nation's gross domestic product-double the current proportion. Cong. Budget Office, Social Security: A Primer, 5 (Sept. 2001) [hereinafterCBO, A PRIMER], available at $\mathrm{ftp}: / / \mathrm{ftp}$. cbo.gov/32xx/doc3213/EntireReport.pdf (last visited Feb. 25, 2004). Alone, spending on Social Security is estimated reach nearly $6.5 \%$ of the gross domestic product by 2030. Id. at $i \& 6$ fig. 2 .

271. See United States v. Sioux Nation of Indians, 448 U.S. 371, 387 \& n.17 (1980) (noting compensation for unconstitutional takings is an exception to the general rule that interest is not awarded in satisfaction of claims against the United States).

272. See Steward Mach. Co. v. Davis, 301 U.S. 548, 574 (1937). 
government retention of the tax proceeds. This distinction, after all, was critical in the Court's ruling on Social Security's constitutionality. ${ }^{273}$

Notwithstanding the challenges in formulating the "just compensation," it seems quite clear that a remedy is possible. Such a realization can only lead to one conclusion: Congress can terminate Social Security at will. Of course both the political and economic ramifications of Social Security's termination make such action laughably remote. Far more likely is a measured plan to extend Social Security's solvency and to guarantee payments to the nation's retirees into the indefinite future. Unfortunately, overlooked in the Social Security debate is the fact that many of the various proposals to reform Social Security, such as raising the retirement age and the creation of private retirement accounts, risk impinging the very same rights that prohibit the programs complete termination without providing "just compensation."

Does the Fifth Amendment permit Congress to raise the retirement age retroactively to apply to current Social Security contributors? Or would such action interfere with the property interest of an individual who "bought in" with the prospect of receiving retirement benefits at a specific age? If individuals were permitted to invest their Social Security withholdings in private investment accounts, would the government be responsible for any losses incurred through such investments? ${ }^{274}$ Such changes to the rules of Social Security such as the retirement age or the manner in which benefits are calculated might be more appropriately analyzed as a regulatory taking, akin to zoning ordinances which tend not to completely eliminate the value of the underlying property, but rather affects the investment-backed expectations. ${ }^{275}$

No matter how unlikely, categorical termination of the Social Security program provides the appropriate starting point for any analysis of the nature of the interest a contributor holds in her future Social Security benefits. As the very concept of its creation, Social Security payments are a right which is earned through contribution. Social Security is not a welfare program designed to provide the impoverished with the means for existence, but a federal pension system more akin to a contract than an unfunded promise. Both the individual and the employer purchase old-age insurance directly

273. Id. at 583 (holding that although the form of a tax is less important than its substance, "[t]he tax being an excise, its imposition must conform to the canon of uniformity").

274. See, e.g, CBO, A PrIMER, supra note 270, at 59-69 (discussing the possibilities and implications for privatization plans).

275. See Brown,123 S. Ct. at 1417-19 (discussing the differences between a regulatory taking where there is a restriction placed on a property interest, and a per se taking which effects a confiscation of an interest in the underlying property). 
through tax contributions. Payment into the program confers a right to receive benefits simply upon reaching a specified age.

Reliance on this right is the rational economic result of the structure of the program and even further encouraged by the government through its own publications. Social Security has the effect of reducing individual savings in reliance on the expectation of future payments. And even though Social Security has faced funding crises, Congress has never contracted the program, making such reliance wholly reasonable.

From the preceding discussion, certain facts about Social Security become clear: a qualified contributor to the old-age insurance plan has a right to receive regular payments after retirement; these payments may not be arbitrarily terminated by the government without due process of law and just compensation; and Social Security's future is in trouble-the Trustees reported an actuarial deficit with total exhaustion of the trust fund in less than fifty years. As Justice Black commented:

[Congress] could repeal the Act so as to cease to operate its old-age insurance activities for the future .... [I]t could stop covering new people, and even stop increasing its obligations to its old contributors. But that is quite different from disappointing the just expectations of the contributors to the fund ... . ${ }^{276}$

Merely reserving the right to alter or amend the old-age insurance system does not disclaim the very right that the Social Security Act was intended to create. 